\title{
Integrating groundwater stress in life-cycle assessments - An evaluation of water abstraction
}

Gejl, Ryle Nørskov; Bjerg, Poul Løgstrup; Henriksen, H. J.; Hauschild, Michael Zwicky; Rasmussen, J.; Rygaard, Martin

Published in:

Journal of Environmental Management

Link to article, DOI:

10.1016/j.jenvman.2018.05.058

Publication date:

2018

Document Version

Peer reviewed version

Link back to DTU Orbit

Citation (APA):

Gejl, R. N., Bjerg, P. L., Henriksen, H. J., Hauschild, M. Z., Rasmussen, J., \& Rygaard, M. (2018). Integrating groundwater stress in life-cycle assessments - An evaluation of water abstraction. Journal of Environmental Management, 222, 112-121. https://doi.org/10.1016/j.jenvman.2018.05.058

\section{General rights}

Copyright and moral rights for the publications made accessible in the public portal are retained by the authors and/or other copyright owners and it is a condition of accessing publications that users recognise and abide by the legal requirements associated with these rights.

- Users may download and print one copy of any publication from the public portal for the purpose of private study or research.

- You may not further distribute the material or use it for any profit-making activity or commercial gain

- You may freely distribute the URL identifying the publication in the public portal 


\section{Integrating groundwater stress in life-cycle assessments - an}

\section{evaluation of water abstraction}

Authors: Gejl, R.N. ${ }^{a, b^{*}}$, Bjerg, P.L. ${ }^{a}$, Henriksen, H.Jc, Hauschild, M.Z. ${ }^{d}$, Rasmussen, J.b and Rygaard, M.

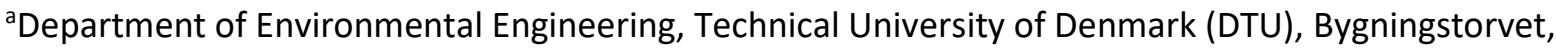
Bygning 115, 2800 Kgs. Lyngby, Denmark

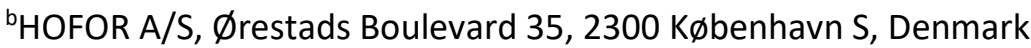

'Geological Survey of Denmark and Greenland, GEUS, Hydrological Department. Øster Voldgade 10, 1350 Copenhagen K. Denmark

${ }^{d}$ Quantitative Sustainability Assessment, Department of Management Engineering, Technical University of Denmark (DTU), Produktionstorvet, Building 424, 2800 Lyngby, Denmark

Submitted for Journal of Environmental Management October 2017

REVIEWERS:

Anne-Marie Boulay, Polytechnique Montréal

Stephan Pfister, ETH Zürich

Tom Gleeson, University of Victoria

Rosemary Knight, Stanford

\section{Keywords}

Groundwater footprint

Water stress 
Groundwater abstraction

AWaRe

LCA

\section{Highlights:}

A proposal for a simple indicator to quantify groundwater abstraction impact

The method uses delineation and data relevant for groundwater at the well-field scale

The method is inspired by state-of-the-art impact and life cycle assessment

The indicator help utilities to manage well-fields and reduce groundwater impacts

\section{Graphical abstract}

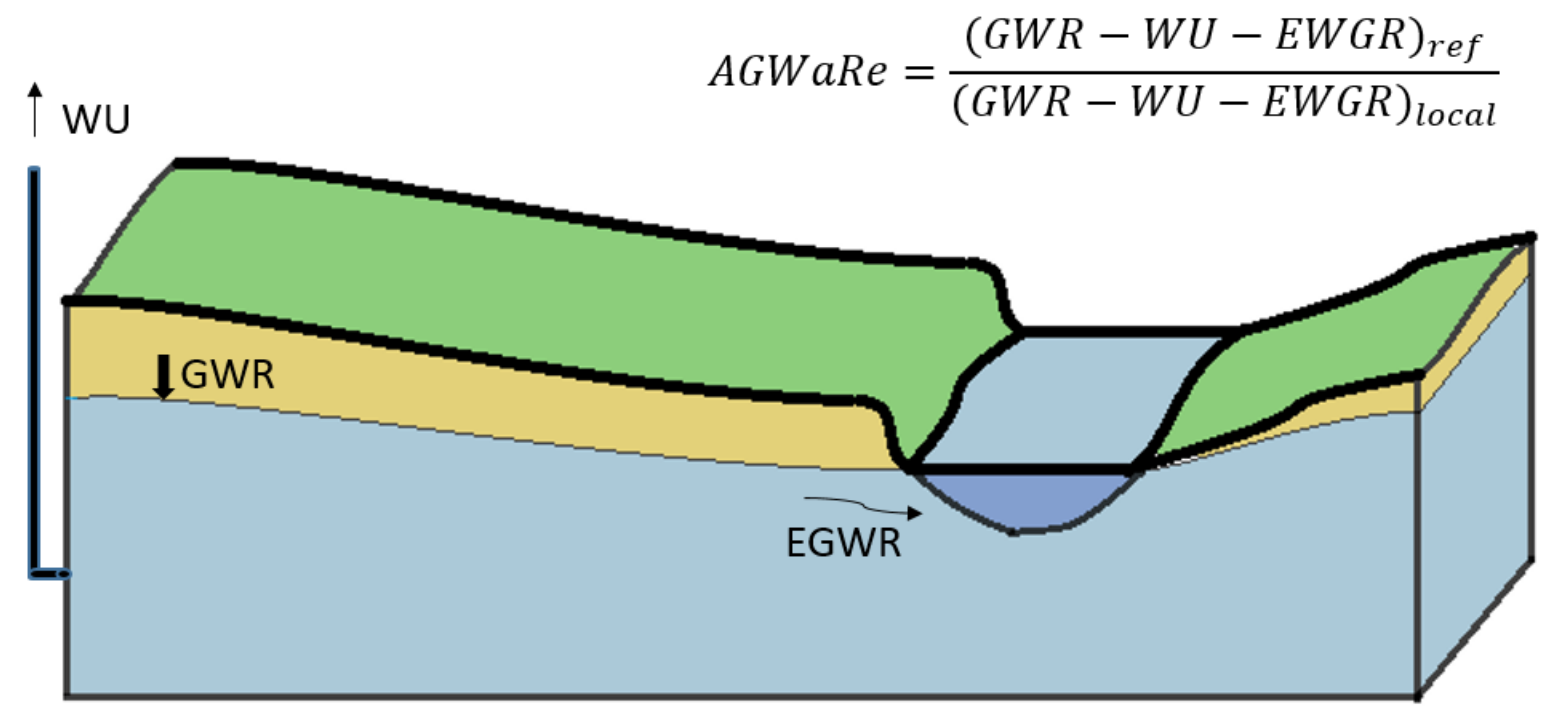

\section{Abstract}

Understanding groundwater abstraction effects is vital for holistic impact assessments in areas depending on groundwater resources. The objective of our study was to modify the state-of-the-art AWaRe (available water remaining), freshwater impact assessment specifically for use in LCAs in areas dependent on groundwater resources. The new method, called "AGWaRe" (available groundwater remaining), reflects groundwater availability, based on a fraction of available 
groundwater remaining locally relative to a reference. Furthermore, our method increases spatial resolution beyond $1770 \mathrm{~km}^{2}$ grid cells and adjusts demarcations in order to improve the representation of the heterogeneity of groundwater catchments. The applicability of AGWaRe was demonstrated on three groundwater systems producing 5 million $\mathrm{m}^{3}$ water for the city of Copenhagen, namely Advanced Treatment of Groundwater, Simple Treatment of Groundwater and Infiltration of Reclaimed water. Results were normalised to compare with other effects of supplying water to an average Danish person. The normalised impacts for drinking water for one person ranged between 0.1 to $39 \mathrm{PE}$ (person equivalent) for the three systems, which indicates that effects on groundwater resources differ substantially between systems. A comparative LCA of these groundwater systems shows that other impact categories range between 0 and $1 \mathrm{PE} /$ person. Advanced Treatment of Groundwater generally has the lowest effect, for example $<50 \%$ of the other groundwater systems in Global Warming Potential. The AGWaRe results indicate that freshwater impacts from Simple Treatment of Groundwater are up to 100 times greater than for Infiltration of Reclaimed water. Furthermore, AGWaRe exposes differences between the groundwater systems that AWaRe cannot evaluate, because one AWaRe cell covers two of the systems in question. These improvements are crucial for groundwater managers looking to include sustainability considerations in their analysis and decision-making.

\section{Introduction}

To protect water resources and ensure its efficient use, there is a need to understand, quantify and assess its condition, and so a range of integrated assessment tools has been developed to this end (e.g. Hoekstra et al. 2011a; Jeswani et al. 2015). Traditionally, impacts are assessed by applying water balances, e.g. withdrawal-to-availability, WTA (Alcamo and Henrichs, 2002), water stress

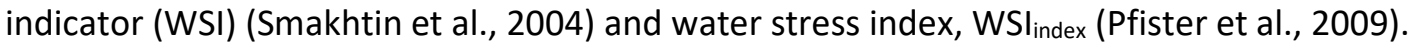
Volumetric water footprints (Hoekstra et al., 2009) represent an important step towards obtaining a freshwater impact, but they do not address issues of local water scarcity (Jeswani and Azapagic, 
2011). A recent suggestion for assessing water use is $A W a R e$, developed by the working group WULCA (Water Use in LCA), which quantifies the available water remaining and thereby assesses the effect of water use based on how much water is left for other uses (Boulay et al., 2017). Contrary to other freshwater impacts, AWaRe does not come with guidelines for interpretation (for example that a score higher than 1 indicates over-exploitation). On the other hand, AWaRe is intuitive, because the result describes how stressed the area is compared to a reference, e.g. the area is $X$ times more water-stressed compared to the world in general. Moreover, AWaRe has the advantage of interpreting the marginal use of water better, in that whereas indicators, such as WSI or WTA, assign equal weight to the first or last cubic metre used, AWaRe puts more weight on the last cubic metre abstracted than the first one. AWaRe has been used in the assessment of green water flows (Quinteiro et al., 2018) and for different productions (Northey, Madrid López, Haque, Mudd, \& Yellishetty, 2018; Villanueva-Rey et al., 2018).

Current AWaRe calculations are based on global spatially differentiated datasets available for grid cells $0.5^{\circ}$ by $0.5^{\circ}$ (Schmied et al., 2014), which compares to $55 \mathrm{~km}$ by $55 \mathrm{~km}$, or $3025 \mathrm{~km}^{2}$ at the equator or approximately $1770 \mathrm{~km}^{2}$ in Denmark. Within each grid cell, availability minus demand $(A M D)$ is compared to $A M D_{\text {world. }}$ Availability here refers to freshwater recharge, and demand refers to both human and environmental demands. AWaRe is defined as a discontinuous function with a cut-off value below 0.1 and above 100. The AWaRe indicator ranges from 0.7 to 6 for Denmark in non-coastal areas (WULCA, 2014). Around the Danish capital Copenhagen, there are four AWaRe grid cells, with scores ranging from 1.4 to 3 . However, with more than 57 well fields, 557 abstraction boreholes and 14 waterworks supplying Copenhagen with water, it is relevant to assess the water stress level at much higher resolutions (Ansorge and Beránková, 2017). A more precise indication of water stress is crucial in the optimisation of future abstraction rates and benchmarking between well fields and waterworks. 
The groundwater resource is influenced by many factors and constitutes a complex system, including difficult catchment delineation, long storage times and complicated interactions between aquifers (Gleeson et al., 2012b). As a result, there is a need to develop a comprehensive understanding of groundwater systems and dynamics. Evaluation tools for water resources have generally focused on surface water, but the Groundwater Directive (European Union, 2006) has increased the focus on groundwater. The importance of groundwater stress levels was highlighted in an assessment of the world's largest groundwater aquifers using a groundwater footprint approach (Gleeson et al., 2012a). The study showed that several international groundwater bodies have excessive water abstraction and in some aquifers, areas 20 times larger than the actual aquifer area were needed to secure a sustainable recharge rate. However, such assessments do not assess freshwater impacts on the local or sub-river basin scale, and so the methods need adaptation for use in local water supply planning.

In light of the Life Cycle Initiative endorsement of AWaRe in their Guidance for Indicators (Life Cycle Initiative, 2016), we chose to modify AWaRe, specifically with groundwater resource management in mind. The aim was to come up with groundwater use impact scores that would be compatible with AWaRe scores or other freshwater use indicators. This is particularly relevant because surface water and groundwater systems are linked closely in the hydrological cycle and are relevant to consider together.

With a Danish water supply entirely dependent on groundwater resources, substantial efforts have been dedicated to understanding the availability and quality of the national groundwater resource. Assessments include a detailed quantification of groundwater flows and analyses of sustainable groundwater abstraction based on the national groundwater model (termed the DK model) with a grid size of $0.25 \mathrm{~km}^{2}$ (Henriksen and Refsgaard, 2013). Datasets for such a high resolution can provide valuable inputs and details in water stress assessments. It is therefore useful to modify the AWaRe 
method so it can take advantage of high-resolution data for groundwater-based water supplies, when available.

Life cycle assessment (LCA) is a tool employed to assess environmental impacts within different categories associated with emissions and extractions occurring across all stages of a product's life, from cradle to grave (European Commission, 2010a). With LCAs being applied to more waterintensive activities (Godskesen et al., 2011; Meron et al., 2016), it is essential to include effects of freshwater use. There are few published LCA studies on groundwater systems (Meron et al., 2016), one of which compared four water supply alternatives and documented the relevance of including a freshwater abstraction impact category (WSI) on a local scale (Godskesen et al., 2013).

The objective of our study is to modify the AWaRe method for use in LCAs, in regions or countries highly dependent on groundwater. Additionally, it is the aim to increase spatial resolution beyond $1770 \mathrm{~km}^{2}$ grid cells and adjust demarcations, in order to represent better the heterogeneity of groundwater catchments. These efforts will take advantage of detailed groundwater data and the high resolution in the DK model for the study area on Zealand, Denmark.

The method is demonstrated by the investigation of environmental trade-offs for three alternative groundwater systems providing drinking water to approximately 1 million inhabitants in Copenhagen. Copenhagen is particularly relevant, because the drinking water supply is entirely dependent on groundwater resources, and it is a continuous challenge to balance water abstractions with environmental water requirements. Specifically, the water utility experienced a contamination with perchloroetheylene (PCE) in a well field producing 5 million $\mathrm{m}^{3}$ of water, which is a substantial amount compared to the total abstraction of 50 million $\mathrm{m}^{3}$ to Copenhagen. To discover changes in effects on the local groundwater bodies (GWBs), we assessed these systems with and without abstracting 5 million $\mathrm{m}^{3}$ of water. The three systems assessed were (Figure 1): a) advanced treatment of contaminated groundwater (ATGW), b) simple treatment of groundwater (STGW) and 
c) infiltration of reclaimed water (IRW) for further details of the three water systems see table 1 and for qualitative data see supplementary information SI. 1.

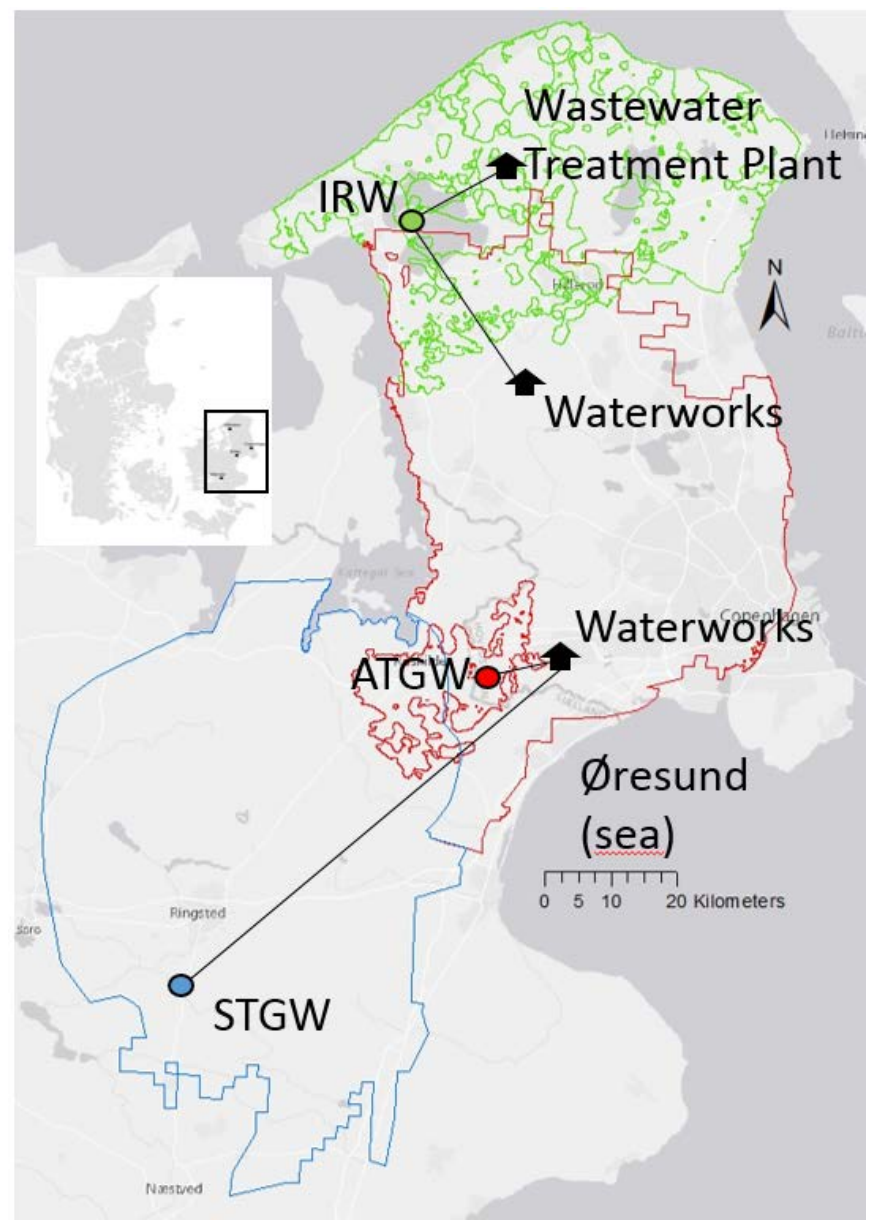

Figure 1: The geographical locations of the three groundwater systems. The colours represent the extent of GWBs connected to each system: ATGW; Advanced treatment of polluted groundwater (red); STGW; Simple treatment of groundwater (blue) and IRW; Infiltration of reclaimed water (green).

Table 1: Information about GWBs connected to the three groundwater systems. Groundwater exploitation is given as the indicator withdrawal-to-availability (WTA) (Alcamo and Henrichs, 2002) for the GWB where we expect an abstraction, for data see table 2.

$\begin{array}{ll}\text { Number of GWBs at the } & \text { GWB exploitation } \\ \text { location and main typology } & \text { (WTA) }\end{array}$

ATGW - Advanced treatment of polluted

2

0.77

groundwater

Severe water stress 


\begin{tabular}{lll}
\hline & Deep aquifer, chalk, regional & \\
STGW - Simple treatment of groundwater & 1 & 0.67 \\
IRW - Infiltration of reclaimed water & Deep aquifer, chalk, regional & Severe water stress \\
& GWB & 0.03 \\
& 3 & Low water stress \\
\hline
\end{tabular}

\section{Methods}

\subsection{The specific effect of local groundwater}

AWaRe calculates the water balance indicator Availability Minus Demand (AMD) (Boulay et al., 2016):

$$
A M D_{i}=W R_{i}-E W R_{i}-W U_{i}
$$

where $i$ refers to the area being assessed. In line with other freshwater impact assessments, it is based on renewable freshwater or net-precipitation (WR), environmental water requirements (EWR) and consumptive water use (WU), all given in $\mathrm{m}^{3} / \mathrm{m}^{2}$.

Inversing the function creates an indicator that emphasizes a unit water use in areas with less water available over water use in areas with a larger resource available. To help the interpretation of AWaRe, AMD scores are related to the global $A M D$ value, $A M D_{\text {World: }}$

$$
A W a R e_{i}=\frac{A M D_{\text {world }}}{A M D_{i}}
$$

WULCA presents global spatially differentiated datasets of characterisation factors (WULCA, 2014), where global flows and storage of water is obtained from the global freshwater model WaterGAP 
(Schmied et al., 2014), and environmental water requirements are based on the variable monthly flow model developed by Pastor et al. (2014).

Our local exploitation impact assessment takes its starting point in the groundwater body (GWB) demarcation, defined by The Groundwater Directive (European Union, 2006). This demarcation is relevant, because it is the scale used by public authorities in groundwater management in Europe. Furthermore, it is defined as an administrative unit consisting of one or several interconnected groundwater aquifers (Troldborg et al., 2014).

Similarly to $A W a R e$, we assess the availability minus demand for groundwater, namely $A M D_{G W, i:}$

$$
A M D_{G W, i}=G W R_{i}-E G W R_{i}-G W U_{i}
$$

where $i$ refers to the GWB being assessed. GWR is the groundwater recharge to the GWB, and EGWR represents environmental groundwater requirements related to baseflow contributions and the preservation of groundwater levels and conditions to prevent long-term environmental problems related to intensive abstraction from aquifers, such as saltwater intrusion etc. (Henriksen et al., 2008). Finally, GWU is groundwater abstraction from the investigated groundwater body, and all figures are given in $\mathrm{m}^{3} / \mathrm{m}^{2}$. Similar to AWaRe, AGWaRe is compared to a reference, in this case the island Zealand, on which Copenhagen is located, $A M D_{\text {zealand: }}$

$$
A G W a R e=\frac{A M D_{\text {Zealand }}}{A M D_{G W, i}}
$$

Comparing to $A M D_{\text {zealand }}$ instead of $A M D_{\text {world }}$ implies that the impacts in this study are local compared to the average groundwater stress on Zealand. Similar to AWaRe, we applied cut-off values below 0.1 and above 100. AGWaRe assigns more weight to the last cubic metre of water used than the first, because as water use approaches the remaining groundwater (GWR-EGWR), the impact increases exponentially (see SI. 2). 
If there is more than 3 metres of clay in between aquifers in a vertical direction, they are delineated as separate aquifers. Two of the groundwater systems were located above more than one delineated groundwater bodies. In these cases the AGWaRe values were based on the groundwater body with the highest recharge, i.e. where we assumed an abstraction would take place.

\subsection{Data, the calculation of EWR and normalisation}

We applied data from the Danish River Basin Management Plans quantitative status assessment for groundwater (Henriksen et al., 2014) using annual average values (from 2005-2010). The data come from the DK model (Højberg et al., 2015), in which GWR in relation to groundwater aquifers is simulated. The DK model of the groundwater resource has 10 to 30 geological layers and 10-15 calculation layers in the saturated zone. Since GWR depends on abstraction (more abstraction leads to more recharge (Henriksen and Refsgaard, 2013)), the GWR in relation to the GWBs is calculated based on model simulations for actual abstractions. The model includes daily precipitation, temperature and evapotranspiration (GEUS, 2009), and the results are compared with runoff figures for more than 200 stream gaging stations and observations of the groundwater table from more than 100,000 groundwater wells (Henriksen and Sonnenborg, 2003; Højberg et al., 2015). GWU is calculated via the DK model, based on data from the national database, JUPITER, provided by GEUS (Geological Survey of Denmark and Greenland), including water statistics from utilities, industrial data and model-simulated agricultural abstractions (Henriksen and Sonnenborg, 2003; Højberg et al., 2015).

EGWR is integrated into assessments undertaken to protect ecological flow regimes, groundwaterdependent ecosystems and aquifer ecosystems. The allocation, magnitude and timing of water for the environment have been discussed for decades, with 'environmental flow (EF)' being defined as "the quantity, quality and timing of water flows required to sustain freshwater ecosystems and the human livelihoods and well-being that depend on these ecosystems" (The Brisbane Declaration, in Forslund \& House, 2009). A screening value of a maximum abstraction of $30 \%$ of GWR (to secure 
aquifer sustainability) has been used in Denmark, estimated empirically and based on an analysis of actual groundwater quality and abstraction rates on the island of Zealand (Henriksen et al., 2008). Since that study did not consider ecological flows, including low flows, these needs were considered later in a separate evaluation as part of the second river basin management plans (Henriksen et al., 2014). Integrating ecological and low flows in EGWR will reduce the proportion available for human consumption, consequently increasing EGWR to $80 \%$ or higher, depending on the acceptable reduction of low flows and ecological flow requirements. In Australia, a study of groundwaterdependent ecosystems recommended a maximum abstraction of 70\% of GWR (Murray et al., 2003). Considering this uncertainty, we chose to apply EGWR values equating to $0 \%, 30 \%$ and $70 \%$ of GWR, acknowledging the need for more research and investigation to estimate appropriate values for EGWR.

To compare results between different impact categories, a normalisation is performed against an external reference impact, to express the scores for different effects in the same unit (person equivalent, PE). This expresses an average person's annual contribution to the impact category (European Commission, 2010a). Normalisation factors for the groundwater impact are estimated at $127.2 \mathrm{~m}^{3} \mathrm{H}_{2} \mathrm{O}$ eq/person/year, based on a 720 million $\mathrm{m}^{3}$ water abstraction rate for public water supply and agriculture in Denmark in 2014 (GEUS, 2015). The normalisation factor is found as the total water abstraction rate divided by a population of 5.6 million (The Danish Statistical Yearbook, 2015), which is then multiplied by the AGWaRe factor for Zealand, with the nominator and the denominator being the same value: $A M D_{\text {Zealand }}$.

\subsection{LCA method}

LCA methodology has four phases: 1) definition of the goal and its scope, 2) an inventory analysis, 3) a life cycle impact assessment and 4) a final interpretation (ISO, 2006).

The goal of the LCA in this study was to investigate the environmental impacts of supplying drinking water to Copenhagen via one of three alternative groundwater-based water supply systems, by 
employing a comparative LCA. The functional unit is a quantitative expression of the service provided by the studied system (European Commission, 2010a). Here, the function of the system is to deliver drinking water to compensate for a well field that is withdrawn from production due to pollution with perchloroethylene. The functional unit is a water production output of 5 million $\mathrm{m}^{3} /$ year for 50 years at a Copenhagen waterworks. Average drinking water consumption is 50 $\mathrm{m}^{3} /$ person in Denmark, and the functional unit thus corresponds to the annual drinking water consumption of 100,000 inhabitants. The AGWaRe method is developed to be generic, but in order to apply as realistic a set of data as possible for the studied systems, we used data and processes provided by the water utility of Copenhagen. The specific systems were chosen based on the utility's discussions of possible locations for infiltration and a new well field. In order not to favour the existing system (ATGW), all constructions and well fields were assumed newly constructed.

The main processes in the modelled systems relate to groundwater abstraction, pipe transport and waterworks, as presented in Figure 3. The assessment includes the impacts associated with water production, from resource abstraction to the water leaving the waterworks. After use, the water is transported to a wastewater treatment plant and treated before being discharged into the sea (Øresund). The impact assessment does not include wastewater treatment, assuming that this is independent of the utilisation of the treated water. We assume the same resource use for personnel transport for all three groundwater systems. Decommissioning of equipment is not included in the assessment, because equipment was assumed similar for the systems and resulting in relatively small contributions over the lifetime of the systems. 


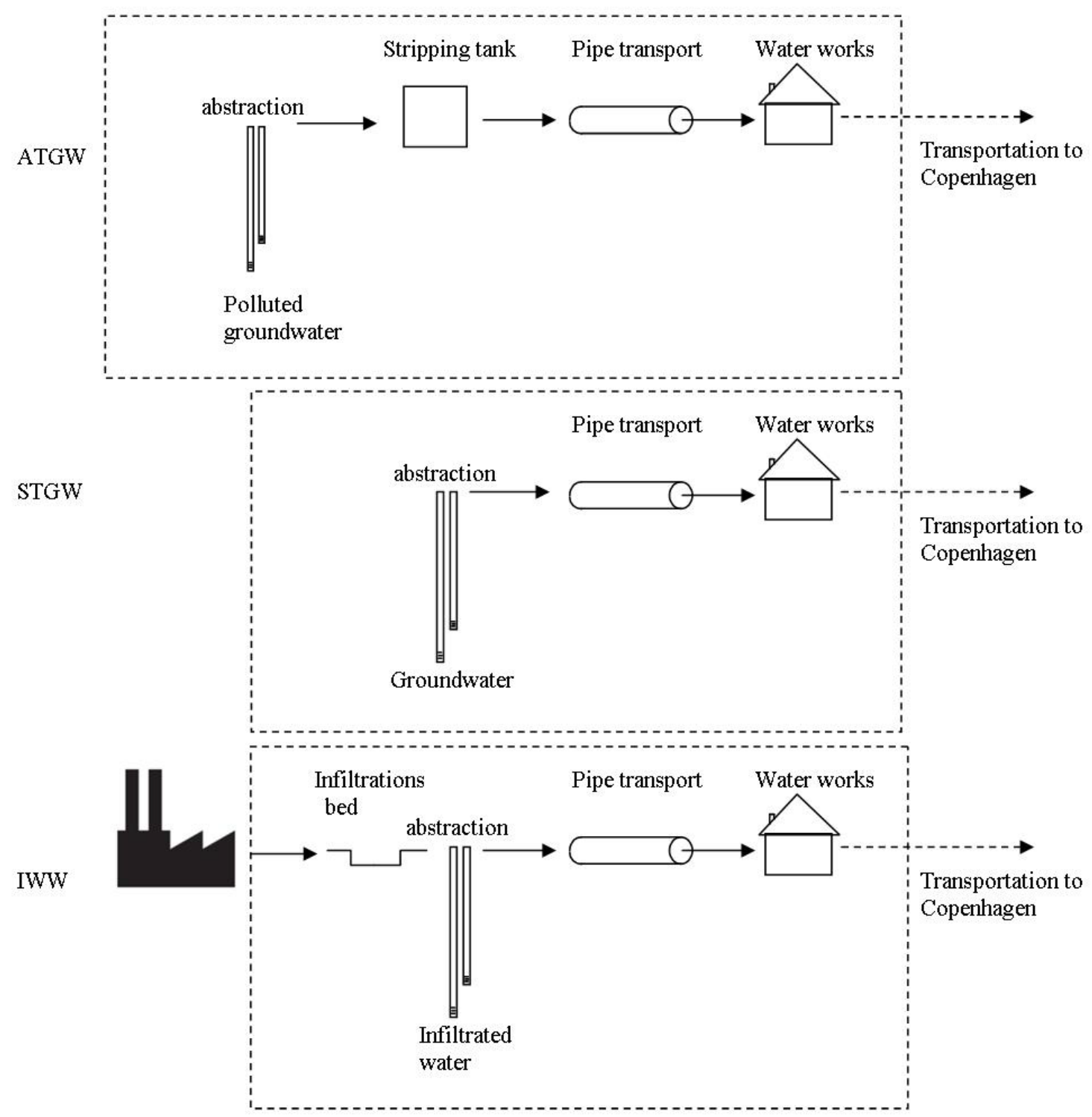

Figure 3: System boundaries for the comparative LCA of three groundwater systems: ATGW: advanced treatment of polluted groundwater; STGW: simple treatment of groundwater and IRW: infiltration of reclaimed water.

ATGW includes a well field and the stripping of the contaminant PCE from abstracted groundwater. The stripping process unit (stripping tank) is situated $5 \mathrm{~km}$ away from the waterworks (Figure 3 ) and is assumed to be performed for the first 10 years, after which the water is transported directly to the waterworks, without stripping. The timing of phasing out PCE stripping reflects the anticipated time needed to remediate the site, in order to protect other groundwater resources and indoor climates in houses situated above the contaminated site (see (Lemming et al., 2010) for further details); however, these activities are not included in our LCA, because they occur regardless of the use of 
this water. STGW includes a well field with clean groundwater, situated $40 \mathrm{~km}$ away from the waterworks, whilst IRW includes the infiltration of treated wastewater and a well field a distance of $20 \mathrm{~km}$ from the wastewater treatment plant to the infiltration plant, and $20 \mathrm{~km}$ from the well field to the waterworks. We increased groundwater recharge, to model infiltration. The water utility estimated that at this location $80 \%$ of the treated wastewater would infiltrate and $20 \%$ would run off or evaporate. It was assumed that reclaimed water will contribute 4 million $\mathrm{m}^{3}$ to $G W R_{\text {inf }}$ and partially compensate for the 5 million $\mathrm{m}^{3}$ extracted for use.

The groundwater systems were chosen based on the utility's discussions of possible locations for a new well field and infiltration. In spite of the focus on a site-specific groundwater system (Copenhagen water supply), the aim is to obtain more general knowledge on trade-offs between different water systems. Materials, chemicals and energy inputs were based on data and general estimations from the water utility in Copenhagen (HOFOR), and actual operational data were used as inputs, when accessible in ATGW. Operations, materials and energy consumption for STGW and IRW were estimated from ATGW and details provided by the water utility. See the inventory in SI. 3, with background processes imported from Ecoinvent (SI. 4; Frischknecht et al., 2005).

The LCA was performed according to ILCD guidelines (European Commission, 2010a), and the impact assessment was performed in EASETECH (Clavreul et al., 2014), which supported 13 out of the 16 recommended impact categories. The results are presented at the midpoint level and normalised using factors developed in the PROSUITE project (European Commission, 2010b). Impacts are expressed in person equivalent (PE), and normalisation relates to the annual effects caused by an average person in Europe (European Commission, 2010a).

Sensitivity analyses were performed, to understand better how sensitive the calculated impacts were to changes in input, and to identify the most influential input data. Three kinds of sensitivity analyses were performed on each of the three groundwater systems. First, a contribution analysis identified processes contributing more than $10 \%$ to any impact category. Second, these processes 
were forwarded to a perturbation analysis and changed by $10 \%$, to estimate the sensitivity of the model's output to parameter input, expressed in sensitivity ratios (Birkved and Hauschild, 2006). The third analysis investigated how a change in assumed power generation system affects the results. The sensitivity analysis for AGWaRe characterisation factors are presented separately.

\section{Results}

Groundwater recharge (GWR) in the studied groundwater bodies varied from 45 to 103 million $\mathrm{m}^{3}$ per year and the abstraction rates varied from 3.4 to 63 million $\mathrm{m}^{3}$ (Table 2). We assume that a new abstraction will only take place in the GWB with the highest recharge and the remaining GWB's are disregarded in this assessment (groundwater flows for all the GWB's located at each groundwater system is seen in SI. 5). The increase in abstraction results in a change of 8 to $147 \%$ compared to the original GWU.

Table 2: Annual groundwater flows in the chosen groundwater bodies for the three groundwater systems, for the current situation. The data are from the DK model (Henriksen et al., 2014) (from 2005-2010).

\begin{tabular}{llllll}
\hline & Area & GWU & GWR & EGWR: 30\% of GWR & EGWR: 70\% of \\
& $\left(\mathrm{km}^{2}\right)$ & $\left(\right.$ million $\left.\mathrm{m}^{3}\right)$ & $\left(\right.$ million $\left.\mathrm{m}^{3}\right)$ & (million $\left.\mathrm{m}^{3}\right)$ & GWR $\left(\right.$ million $\left.\mathrm{m}^{3}\right)$ \\
\hline ATGW & 1160 & 63 & 80 & 24 & 56 \\
STGW & 1315 & 29 & 45 & 14 & 31 \\
IRW & 612 & 3.4 & 103 & 31 & 72 \\
\hline
\end{tabular}

\subsection{The AGWaRe groundwater impact}

An AGWaRe score of 2 represents a local water stress level that is two times higher than the average groundwater stress for Zealand. AGWaRe for groundwater abstraction ranges from 0.2 to 100 for the three systems (Table 3), showing that 1 ) there are large variations in water stress in the three cases within the Copenhagen water extraction area and 2) water stress for two of the water systems attains the highest characterisation factor for EGWR above 30\% (ATGW) and 70\% (STGW) of GWR. These results were expected, since these GWBs was already classified as having severe water stress 
(Table 1) before any additional withdrawal and because they provide water for the most densely populated area on Zealand. Generally, AGWaRe scores increase when larger fractions of the GWB are allocated to the environment. Increasing the GWU by five million $\mathrm{m}^{3}$ makes a change to the impact factors between 0 and $47 \%$ for $0 \%$ EGWR and up to $238 \%$ for $30 \%$ EGWR. As expected, the groundwater system with the highest characterization factor (STGW) also saw the highest change in impact, because AGWaRe grows exponentially when the remaining reserve decreases (cf. SI. 2). In other words, groundwater resources already with high water stress will achieve large changes in impact factors when increasing abstraction.

Table 3: AGWaRe characterization factors without and with an additional 5 million $\mathrm{m}^{3}$ water abstraction and the relative change in impact factor from a situation without additional abstraction. Non-agriculture AWaRe characterization factors are based on (WULCA, 2014). AGWaRe results are based on annual averages (2005-2010) from the DK model (Henriksen et al., 2014).

\begin{tabular}{|c|c|c|c|c|c|c|c|c|c|c|}
\hline \multirow[b]{3}{*}{ EGWR (\% of GWR) } & \multirow{2}{*}{\multicolumn{3}{|c|}{$\begin{array}{l}\text { AGWaRe 'without' } \\
\text { additional } 5 \text { mill m³ }\end{array}$}} & \multirow{2}{*}{\multicolumn{3}{|c|}{$\begin{array}{l}\text { AGWaRe 'with' } \\
\text { additional } 5 \text { mill m³ }\end{array}$}} & \multirow{2}{*}{\multicolumn{3}{|c|}{$\begin{array}{l}\text { Change in AGWaRe from } \\
\text { 'without' to 'with' (\%) }\end{array}$}} & \multirow{3}{*}{$\begin{array}{l}\text { AWaRe by } \\
\text { WULCA }\end{array}$} \\
\hline & & & & & & & & & & \\
\hline & $0 \%$ & $30 \%$ & $70 \%$ & $0 \%$ & $30 \%$ & $70 \%$ & $0 \%$ & $30 \%$ & $70 \%$ & \\
\hline ATGW & 2.5 & 100 & 100 & 3.2 & 100 & 100 & 28 & 0 & 0 & 1.4 \\
\hline STGW & 4.1 & 29.6 & 100 & 6.0 & 100 & 100 & 47 & 238 & 0 & 1.9 \\
\hline IRW & 0.3 & 0.4 & 1.1 & 0.3 & 0.4 & 1.1 & 1 & 1 & 4 & 1.4 \\
\hline
\end{tabular}

AGWaRe indicates that ATGW is the most water stressed of the three systems, then STGW and lastly IRW, except for EGWR set to 0\% where STGW is the most stressed. Results based on AWaRe and AGWaRe cannot be compared easily due to differences in scale and boundary conditions. AWaRe is based on exploitation compared to renewable resources (net precipitation) and has a much lower spatial data resolution. Nevertheless, the rankings of groundwater systems in terms of water stress appear relevant to consider. Where AGWaRe ranks STGW as the most water stressed, the AGWaRe only has similar ranking, for EGWR set to $0 \%$. AWaRe has the same impact score for ATGW and IRW, because they are within the same AWaRe grid cell (40 km apart). On this local scale, AGWaRe provided further information and a more detailed assessment and revealed that IRW has markedly less effect on water resources than ATGW (Table 3). 
Normalised groundwater impacts (Figure 4) from the three groundwater systems were calculated by multiplying the AGWaRe characterisation factor by resource use $\left(5\right.$ million $\left.\mathrm{m}^{3}\right)$ and dividing by the normalisation factor (127.2 $\mathrm{m}^{3} \mathrm{H}_{2} \mathrm{O}$ eq./PE/year). Hence, the drinking water consumption of 100,000 people in Copenhagen constitutes an impact corresponding to 0.04 to 3.9 MPE, depending on where the water is abstracted and what share is assumed for EGWR. These results correspond to impacts ranging between 0.4 and $39 \mathrm{PE}$ for one person. In other words, depending on the choice of groundwater system, our results indicate an imposed water stress ranging from one-third (IRW) to more than 30 times (STGW) of the person-averaged water stress on Zealand.

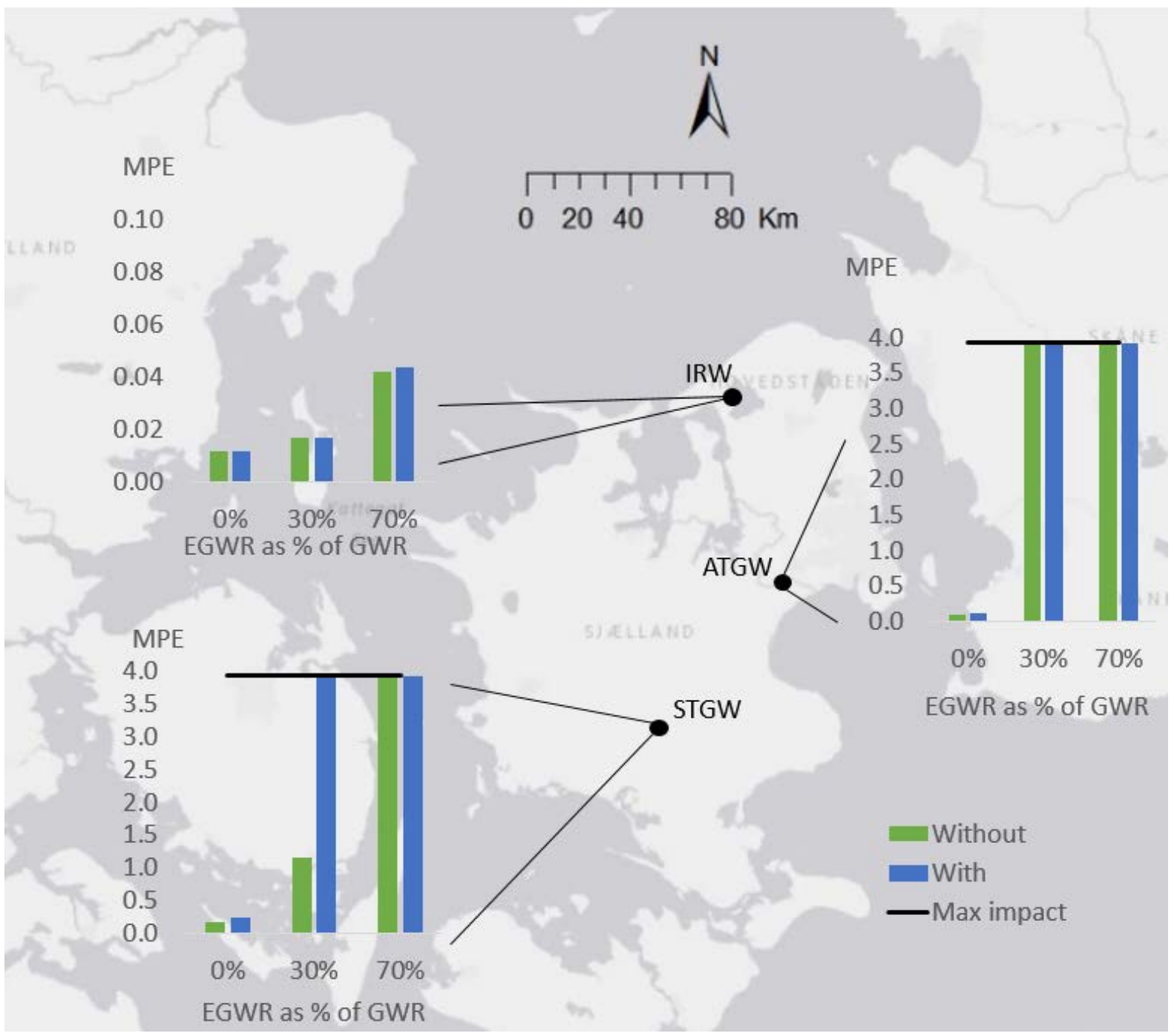

Figure 4: The location of the estimated groundwater impact for different allocations of EGWR (x-axis) for the three groundwater systems, with (blue) and without (green) 5 million $\mathrm{m}^{3}$ groundwater abstraction. The groundwater impact is 
calculated by multiplying the characterisation factor (AGWaRe) by the inventory (water use) and dividing by the normalisation factor. MPE is million person equivalents. Please note a different y-axis for IRW.

\subsection{LCA impacts for three groundwater systems}

The conventional LCA impact scores ranged between 1 and 874 PE for the three groundwater systems supplying water for 100,000 inhabitants. For 12 out of the 14 impact categories, IRW was the groundwater system with the highest environmental impacts, followed by STGW and then ATGW with the lowest impacts. For example, the global warming potential was 72,167 and $170 \mathrm{PE}$ for ATGW, STGW and IRW, respectively. See the results for all impact categories, (SI. 6).

Figure 5 shows the contribution made by different processes to the impact categories abiotic resource depletion (reserve base), global warming potential and human toxicity (carcinogenic). The four main contributory processes were abstraction, transportation of water by pipes, waterworks and the treatment of contamination, collectively accounting for more than $76 \%$ for 12 out of the 14 impact categories and up to $99 \%$ of the global warming potential (the only exceptions were stratospheric ozone depletion and ionising radiation SOD, with impacts below 8PE). As a result, impacts from the systems caused roughly $1 \%$ of the contribution of an average person in Copenhagen to abiotic resources depletion (reserve base), which was the impact category with highest impacts. The environmental performance of all three systems was sensitive to the assumed scenario for electricity generation. For the most efficient electricity-consuming system, namely ATGW, electricity alone constituted $63 \%$ of the global warming potential.

For the objective of lowering environmental impacts, many processes would require improvement, and none of the processes dominated all impact categories. Pipe transport was the main contributor to global warming potential for example $86 \%$ for STGW. 


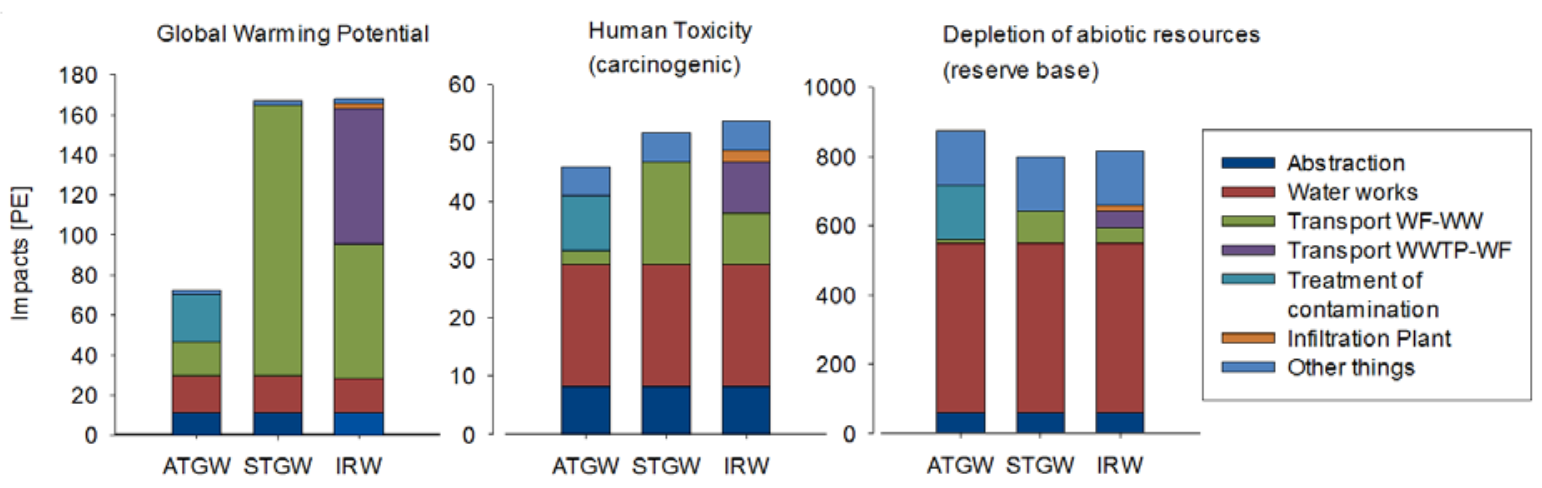

Figure 5: Process contribution to the impact categories 1) global warming potential, 2) human toxicity, carcinogenic and 3) abiotic resources depletion (reserve base).

An LCA reflects environmental impacts in relation to choices in water supply management, and hence it can help decision making in water supply. However, a traditional LCA does not highlight effects on water resources, which is perhaps the most relevant impact when assessing water abstraction or use.

\subsection{LCA including a groundwater impact}

AGWaRe and the five impact categories with the highest scores in the conventional LCA are presented in Figure 6. As evident from the results presented in the previous sections, the groundwater impact is dramatically greater than the LCA impacts from the drinking water systems. This result is to be expected, though, as drinking water production is the main activity in Denmark responsible for extracting this resource, while the other impact categories are affected by most human activities including transport and energy provision. To compare results for the three systems, an internal normalisation was performed for the impact scores against the highest score in each impact category, as illustrated in Figure 6. The patterns for STGW and IRW are similar, except for AGWaRe, which varies most between the cases, and it is therefore an important impact category to include in environmental assessments, in order to obtain a more complete understanding of the effects associated with groundwater abstraction. Assigning equal weight to the impact categories, the groundwater impact dominates and STGW is the groundwater system with the highest impacts. 
Disregarding the groundwater impact, IRW is the groundwater system with the highest environmental impacts.

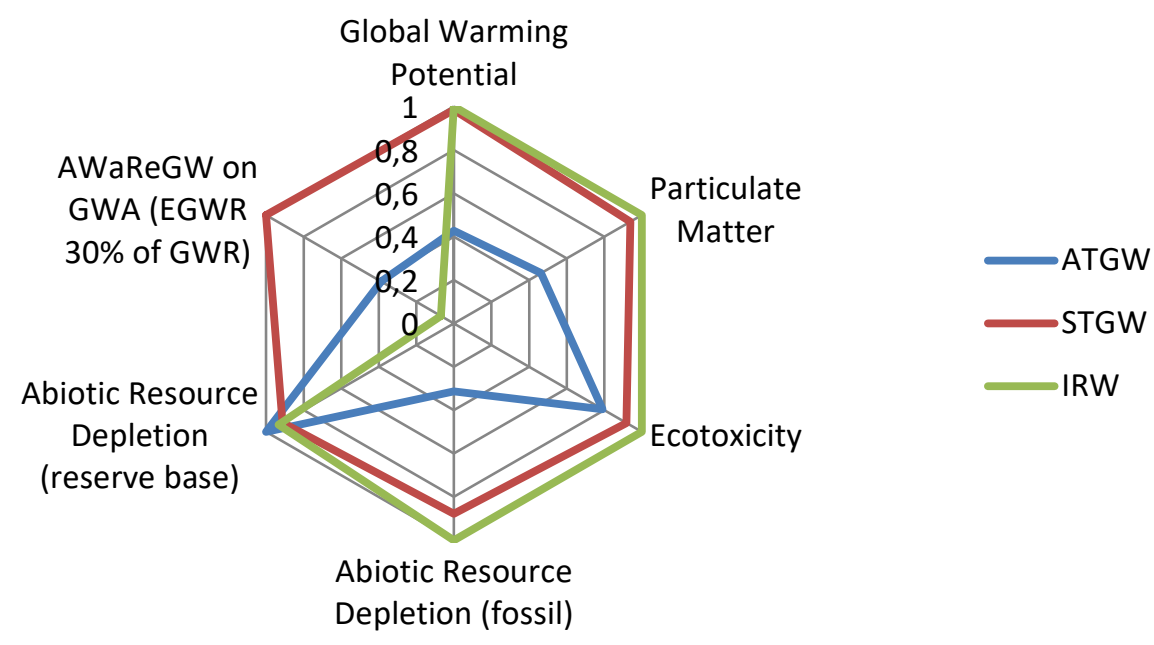

Figure 6: Comparison of three groundwater systems producing 5 million $\mathrm{m}^{3}$ of water. Scores are normalised against the highest impact within each category for current abstractions, and EGWR is set to $30 \%$.

\subsection{Uncertainties}

\subsubsection{Uncertainty of AGWaRe}

The results in this study are based on running the DK model for actual groundwater abstractions. For two of the groundwater systems (IRW and STGW), we assumed increased abstractions without increasing groundwater recharges, however it is likely that groundwater recharge is highly dependent on abstraction. In our case, an increased recharge to the GWB as a result of increased abstraction would favour ATGW over IRW and STGW. To increase the precision of groundwater recharges, the model should have been run individually for each groundwater system. While increased natural recharges would probably change the characterisation factors it is assumed not to affect the overall results and conclusions. For example, ATGW, with an abstraction of 5 million $\mathrm{m}^{3}$ of water, has a lower AGWaRe than STGW without abstraction (for EGWR set to 0\% or 30\%). For STGW, which has the highest AGWaRe, increased water abstraction constituted less than $2 \%$ of the total 
water abstraction from this location, and it is therefore not expected to change the ranking of the results in our case.

Quantities computed by a hydrological model are highly dependent on their input, so we investigated the sensitivity of AGWaRe to changes in GWU, GWR and EGWR by conducting a perturbation analysis, resulting in sensitivity ratios. Since there were only three input parameters in AGWaRe, the sensitivity ratios were relatively high, up to 33.3 , corresponding to a $333 \%$ change in AGWaRe based on a 10\% change in GWR, as illustrated in Table 4. As expected, an increase in water consumption increased the impact, and increases in groundwater recharge decreased the impact. The high sensitivity ratios demonstrate the importance of improving the accuracy of water flows, since a relatively small change in one of them can result in a large difference in impacts.

Table 4: Sensitivity ratios (SR) for the inputs in AGWaRe for the three groundwater systems with EGWR set to $30 \%$ of groundwater recharge.

\begin{tabular}{lccc}
\hline SR & GWU +10\% & GWR +10\% & EGWR +10\% \\
\hline ATGW & 0 & -3.5 & 0 \\
STGW & 7.9 & -6.5 & 7.9 \\
IRW & 0 & -1.3 & 0.5
\end{tabular}

As expected STGW is the most sensitive, because it has the highest AGWaRe characterisation factors. However, ATGW is forcedly low, due to the cut-off at 100, AGWaRe was leveled off (cf. SI. 2), which means that AGWaRe would not change further, with an increase in groundwater use. Similarly, the cut-off was also the reason for STGW having similar sensitivity to changes in GWU and EGWR.

\subsubsection{Uncertainty of the LCA results}

A contribution analysis was undertaken for the modelled systems, as provided in SI. 7. All of the modelled processes contributed more than $10 \%$ to at least one of the impact categories. The perturbation analysis hence showed that the system was sensitive to many different inputs. The 
three highest sensitivity ratios are shown in SI. 8, relating to abiotic resource depletion (reserve base), global warming and human toxicity (carcinogenic). The highest sensitivity ratio was 0.73 for the global warming potential's sensitivity to the energy used for pipe transport for STGW. This compares to a $7 \%$ increase in the climate change impact, based on a $10 \%$ increase in electricity consumption for pipe transportation. The global warming impact category was the most sensitive to the use of energy, because fossil fuels are still important energy carriers in Denmark. The other impact categories had several influential parameters, but overall, the systems were sensitive to energy consumption.

Considering the sensitivity to electricity consumption, we chose to analyse how a planned shift of the Danish power supply system towards renewable energy sources would change the impacts. Energy in the foreground was changed from energy-mix-DK (current electricity consumption in Denmark (EC_JRC, 2002)) to wind energy, and then the effects from the different energy sources were compared in SI. 9 for three impact categories, namely global warming potential, human toxicity (carcinogenic) and abiotic resources depletion (reserve base). As expected, when modelling with electricity supplied by wind energy, there were lower impacts in most categories. Global warming potential, for instance, decreased by two-thirds in ATGW and by $90 \%$ in STGW and IRW. The ranking of the groundwater systems remained unchanged, however, with IRW having the highest impact in 12 out of the 14 categories.

\section{Discussion}

It was proven possible to integrate groundwater exploitation impacts in environmental assessments, which is a step towards more holistic decision support in water management. Furthermore, including water impacts in LCAs is vital for the future relevance of LCA studies.

AWaRe gives a good insight into water stress around the world, e.g. for analysing world supply chains, but provides little assistance in choosing or prioritising between well fields on a scale finer than $1770 \mathrm{~km}^{2}$. The AWaRe impacts have similar values for the three groundwater systems, and for 
two of them it has identical values, because they are within the same grid cell. Therefore, with the current available dataset AWaRe cannot provide support for future decisions on water supply management in Zealand, since the grid is not a relevant scale for their abstraction.

\subsection{Local and groundwater-specific impacts}

AGWaRe is able to distinguish the quantitative status between different aquifers and groundwater bodies according to their overall water stress situation, which is useful for prioritising between different groundwater systems, in order to minimise the overall groundwater abstraction impact, e.g. for managing exploitation degrees between several well fields. The AGWaRe reflects expected groundwater impacts from the water utility and in relation to groundwater recharges to the aquifer, both of which contribute to the reliability of the indicator.

Interestingly, AGWaRe and traditional water balances (WTAs) suggest different groundwater systems as the most water-stressed (comparing Tables 1 and 3). AGWaRe suggests that for EGWR set to $0 \%$ STGW is the most stressed, whereas WTA suggests that ATGW is most stressed. This is because where WTA indicates the degree of exploitation, AGWaRe indicates water stress compared to average Zealand conditions based on how much $\mathrm{m}^{3} / \mathrm{m}^{2}$ remains. STGW has the highest exploitation percentage, and at the same time more $\mathrm{m}^{3} / \mathrm{m}^{2}$ than ATGW. Therefore, the two indicators suggest different groundwater systems as the most stressed. The rankings of the GWBs in this study, when using AGWaRe, comply with earlier studies on sustainable groundwater abstraction in Denmark (Henriksen et al., 2014).

This study suggests that the GWBs constituting the basis of the water supply for Copenhagen could be relieved by abstracting water from other, less exploited GWBs, thereby alleviating overall groundwater stress. If shallow GWBs are chosen, a further improvement of shallow groundwater quality by additional groundwater protection may be required as well as adverse effects of such an abstraction on groundwater-dependent ecosystems is crucial, since these systems has direct contact to surface water and shallow groundwater systems in many areas. 
AGWaRe complements the LCA findings, because it introduces water consumption impacts to the established set of LCA impact categories at a scale relevant for decision-making in water utilities. Future work should focus on how to harmonise a standard method and scale, and prepare groundwater datasets for more areas, preferably covering areas outside Denmark too.

\subsection{Scale and assumptions}

In order to obtain a relevant and consistent groundwater impact, the issues of scale and demarcation have to be addressed further (Hybel et al., 2015). A relevant scale is one where there is an actual impact, for example the extent to which the groundwater impact is observed. The scale applied in this study allowed for identifying areas with high water stress that were otherwise hidden on a larger scale (Eldardiry et al., 2016). Although the study is restricted to a specific region, a similar approach can be used on other geological and environmental conditions by carefully selecting scale and boundary conditions. The local scale provides advantages, as mentioned beforehand, but it also has some constraints as follows. First, assessing local impacts requires access to detailed, highresolution groundwater data, which in many situations are not available but would nevertheless increase the relevance of the assessments (Lévová and Hauschild, 2011). Second, if the objective is to understand water stress on a global or a national level, the local scale can give too much information for an overview. On the other hand, a national average can obscure the fact that there are large problems in certain locations, if the general situation is good (Mutel et al. 2012). Finally, using specific and detailed data for a case makes comparison with other cases outside the study area difficult, because these would require similar data backgrounds and assumptions.

Several of the groundwater systems had the highest AGWaRe characterisation factor (100), which may be a result of choosing intensively exploited groundwater systems providing water to the most densely populated area in Denmark. AGWaRe would be more relevant for the water utility if the highest impacts were only reached in water-stressed situations and not as a function of using more water than the reference. With the available dataset, we expect GWU and GWR to have little 
uncertainty connected to them, while EGWR is based on crude estimations. A reduced EGWR would ensure fewer cases obtaining the highest AGWaRe score. Another possibility is to change the cut-off. We applied the cut-off values used in the AWaRe method, in order to balance the effect on the impact from inventory and geographical water stress (Boulay et al. 2016), but their choice of cut-off was based on the overall water cycle, and it could possibly be optimised for groundwater systems. A third option is to change the reference, for example substituting the average reference with a sustainable reference; instead of comparing to the average of Zealand, the groundwater systems are compared to a defined sustainable groundwater abstraction. Additionally, this would lead to an easily interpretable indicator, with for example two times the sustainable groundwater abstraction.

Noteworthy at this local scale, increasing EGWR does not necessarily increase AGWaRe, because the regional reference also changes with an increasing $E G W R$, and if $A M D_{i}$ is affected less than $A M D_{\text {zealand, }}$ the characterisation factor will diminish in line with an increased EGWR. This is an argument for stating AMD along with AGWaRe, because AMD is absolute and AGWaRe is relative. Furthermore, AGWaRe characterisation factors can only be used to compare results with the same reference (in this case Zealand), while $A M D_{i}$ is comparable across global locations, as long as their calculation is based on similar assumptions.

The groundwater impact developed in this study is only related to quantities of water, neglecting water quality issues, so future work should integrate water quality, including the relationship between natural groundwater quality and groundwater exploitation and groundwater pollution caused by land use (Zeng et al., 2013). Including water quality could also reveal the benefits in ATGW of using polluted water (caused by land use activities), which are unaccounted for in this study. Polluted water is in many cases considered unusable and disregarded from the resource. Thereby, reclaiming polluted water would increase the available water resource. 


\subsection{LCA}

The studied groundwater systems mainly reflect impacts related to water systems in Copenhagen, where energy for pipe transport has a significant influence. The relative importance of energy in a Copenhagen setting also became evident when conventional energy was substituted with wind energy, in which case the impacts decreased substantially.

Generally, there are large differences in water supply systems (Meron et al., 2016), and this is also the conclusion when comparing the results to other findings. For example, the largest impacts are within the resource categories in this study, whereas resource consumption generally had the lowest impacts in another LCA study of Danish water systems (Godskesen et al., 2013). The explanation could be that Godskesen et al. (2013) only accounted for four different resource consumptions, while our study has a broader coverage of resource consumptions. Our paper studies the effect of chlorinated compounds and general groundwater quality. Other water qualities, pollutants or treatment systems can be analysed by changing the treatment or the system boundaries in the assessment, e.g. inclusion of corrosion of the pipe system (Rygaard et al., 2009) or softening of drinking water with high hardness (Godskesen et al., 2012).

With its higher spatial resolution, AGWaRe supports assessments at the relevant scale for water supplies based on groundwater abstraction, and it therefore offers better decision-support. Furthermore, it reflects differences in impacts between adjacent groundwater systems, which is relevant for decision-making in groundwater management. Therefore, AGWaRe is valuable for assisting in regional water management and in formulating regulations. Moreover, when AWaRe is too coarse for evaluating general water stress in an LCA at a local scale, a methodology similar to AGWaRe can be applied. 


\section{Conclusion}

Understanding groundwater impacts is crucial for managing groundwater abstraction efficiently. We developed AGWaRe (available groundwater remaining) to show local groundwater stress overlooked by state-of-the-art freshwater impact assessments. In short, it:

- builds on existing state-of-the-art principles for LCA water stress impact assessment

- shows local water stress impacts as expected from the water utility and earlier studies

- allows for understanding water stress on a scale smaller than national or regional assessments, which is crucial for water utilities

- helps LCA to more holistically assess the impacts of drinking water systems based on groundwater resources

AGWaRe, as part of an LCA, was assessed for three groundwater systems for Copenhagen, Denmark: advanced treatment of contaminated groundwater (ATGW), simple treatment of groundwater (STGW) and infiltration of reclaimed water (IRW). Assigning equal weight to the impact categories, AGWaRe dominated the LCA and STGW had the highest impacts. Disregarding AGWaRe, IRW had the highest impacts. Applying AGWaRe shows that already heavily abstracted aquifers are the basis of Copenhagen's water supply, and overall groundwater stress could be alleviated by moving some of the abstraction to less stressed aquifers.

Acknowledgement: We would like to thank Anders Damgaard for guidance and discussions concerning the EASETECH software applied for the modelling. This work is part of an industrial PhD program conducted at the Technical University of Denmark, supported by Innovation Fund Denmark, HOFOR, VandCenter Syd and Aarhus Vand. 
Alcamo, J., Henrichs, T., 2002. Critical regions: A model-based estimation of world water resources sensitive to global changes. Aquat. Sci. 64, 352-362. https://doi.org/10.1007/PL00012591

Ansorge, L., Beránková, T., 2017. LCA Water Footprint AWARE characterization factor based on local specific conditions. Eur. J. Sustain. Dev. 6, 12-20. https://doi.org/10.14207/ejsd.2017.v6n4p13

Birkved, M., Hauschild, M.Z., 2006. PestLCI-A model for estimating field emissions of pesticides in agricultural LCA. Ecol. Modell. 198, 433-451. https://doi.org/10.1016/j.ecolmodel.2006.05.035

Boulay, A.-M., Pfister, S., Motoshita, M., Schenker, U., Benini, L., Gheewala, S.H., Harding, K., 2016. Global Guidance for Life Cycle Impact Assessment Indicators, Chapter 5a: Water scarcity.

Boulay, A.M., Bare, J., Benini, L., Berger, M., Lathuillière, M.J., Manzardo, A., Margni, M., Motoshita, M., Núñez, M., Pastor, A.V., Ridoutt, B., Oki, T., Worbe, S., Pfister, S., 2017. The WULCA consensus characterization model for water scarcity footprints: assessing impacts of water consumption based on available water remaining (AWARE). Int. J. Life Cycle Assess. 1-11. https://doi.org/10.1007/s11367-017-1333-8

Clavreul, J., Baumeister, H., Christensen, T.H., Damgaard, A., 2014. An environmental assessment system for environmental technologies. Environ. Model. Softw. 60, 18-30. https://doi.org/10.1016/j.envsoft.2014.06.007

EC_JRC, 2002. Electricity Mix; AC; consumption mix, at consumer; $230 \mathrm{~V}$.

Eldardiry, H., Habib, E., Borrok, D.M., 2016. Small-scale catchment analysis of water stress in wet regions of the U.S.: an example from Louisiana. Environ. Res. Lett. 11, 124031. https://doi.org/10.1088/1748-9326/aa51dc

European Commission, 2010a. International Reference Life Cycle Data System (ILCD) Handbook -General guide for Life Cycle Assessment -- Detailed guidance, Constraints. Joint Research Centre - Institute for Environment and Sustainability. https://doi.org/10.2788/38479 
European Commission, 2010b. Final Report Summary - PROSUITE (Development and Application of Standardized Methodology for the PROspective SUstaln- ability Assessment of TEchnologies). Project reference: 227078 .

European Union, 2006. The groundwater directive (Directive 2006/118/EC of the European Parliament and of the council of 12 December 2006 on the protection of groundwater against pollution and deterioration). Off. J. Eur. Union 19, 19-31. https://doi.org/http://eurlex.europa.eu/legal-content/EN/TXT/?uri=CELEX:32006L0118

Forslund, a, House, S.W., 2009. Securing Water for Ecosystems and Human Well-being: The Importance of Environmental Flows, Swedish Water House Report. https://doi.org/978-91$975872-4-2$

Frischknecht, R., Jungbluth, N., Althaus, H.-J., Doka, G., Dones, R., Heck, T., Hellweg, S., Hischier, R., Nemecek, T., Rebitzer, G., Spielmann, M., 2005. The ecoinvent Database: Overview and Methodological Framework (7 pp). Int. J. Life Cycle Assess. 10, 3-9. https://doi.org/10.1065/lca2004.10.181.1

GEUS, 2015. Grundvand Status og udvikling 1989 - 2014 Resumerapport. Energi- Forsynings og Klimaministeriet.

GEUS, 2009. DK-modellen. Hydrological model of Denmark. Description available at: http://vandmodel.dk/vm/om_os/index.html [WWW Document].

Gleeson, T., Alley, W.M., Allen, D.M., Sophocleous, M. a., Zhou, Y., Taniguchi, M., Vandersteen, J., 2012a. Towards sustainable groundwater use: Setting long-term goals, backcasting, and managing adaptively. Ground Water 50, 19-26. https://doi.org/10.1111/j.1745$6584.2011 .00825 . x$

Gleeson, T., Wada, Y., Bierkens, M.F.P., van Beek, L.P.H., 2012b. Water balance of global aquifers 
revealed by groundwater footprint. Nature $488,197-200$.

https://doi.org/10.1038/nature11295

Godskesen, B., Hauschild, M., Rygaard, M., Zambrano, K., Albrechtsen, H.J., 2013. Life-cycle and freshwater withdrawal impact assessment of water supply technologies. Water Res. 47, 23632374. https://doi.org/10.1016/j.watres.2013.02.005

Godskesen, B., Hauschild, M., Rygaard, M., Zambrano, K., Albrechtsen, H.J., 2012. Life cycle assessment of central softening of very hard drinking water. J. Environ. Manage. 105, 83-89. https://doi.org/10.1016/j.jenvman.2012.03.030

Godskesen, B., Zambrano, K.C., Trautner, A., Johansen, N.-B., Thiesson, L., Andersen, L., ClausonKaas, J., Neidel, T.L., Rygaard, M., Kløverpris, N.H., Albrechtsen, H.-J., 2011. Life cycle assessment of three water systems in Copenhagen-a management tool of the future. Water Sci. Technol. 63, 565. https://doi.org/10.2166/wst.2011.258

Henriksen, H.J., Rasmussen, J., Olsen, M., He, X., Troldborg, L., Jørgensen, L.F., 2014. Implementering af modeller til brug for vandforvaltning . Delprojekt : Effekt af vandindvinding Konceptuel tilgang og validering samt tilstandsvurdering af grundvandsforekomster Udarbejdet for Naturstyrelsen.

Henriksen, H.J., Refsgaard, J.C., 2013. Sustainable groundwater abstraction - a review report. Danmarks og Grønlands Geologiske Undersøgelse Rapport. 2013/30. GEUS.

Henriksen, H.J., Sonnenborg, A., 2003. Ferskvandets kredsløb. Danmarks og Grønlands Geologiske Tema Rapport. GEUS.

Henriksen, H.J., Troldborg, L., Højberg, A.L., Refsgaard, J.C., 2008. Assessment of exploitable groundwater resources of Denmark by use of ensemble resource indicators and a numerical groundwater-surface water model. J. Hydrol. 348, 224-240. 
https://doi.org/10.1016/j.jhydrol.2007.09.056

Hoekstra, A.Y., Chapagain, A.K., Aldaya, M.M., Mekonnen, M.M., 2011. The Water Footprint Assessment Manual, Febrero 2011. Earthscan, London, Washington, DC. https://doi.org/978-184971-279-8

Hoekstra, A.Y., Chapagain, A.K., Aldaya, M.M., Mekonnen, M.M., 2009. Water Footprint Manual State of the Art 2009, Water Footprint Network. Water Footprint Network.

Højberg, A.L., Stisen, S., Olsen, M., Troldborg, L., Uglebjerg, T.B., Jørgensen, L.F., 2015. DKmodel2014 Model opdatering og kalibrering.

Hybel, a.-M., Godskesen, B., Rygaard, M., 2015. Selection of spatial scale for assessing impacts of groundwater-based water supply on freshwater resources. J. Environ. Manage. 160, 90-97. https://doi.org/10.1016/j.jenvman.2015.06.016

ISO, 2006. Environmental management - Life cycle assessment — Principles and framework ISO 14044. European Committee for Standards, rue de Stassart, 36, B-1050 Brussels, rue de Stassart, 36, B-1050 Brussels.

Jeswani, H.K., Azapagic, A., 2011. Water footprint: Methodologies and a case study for assessing the impacts of water use. J. Clean. Prod. 19, 1288-1299.

https://doi.org/10.1016/j.jclepro.2011.04.003

Jeswani, H.K., Burkinshaw, R., Azapagic, A., 2015. Environmental sustainability issues in the foodenergy-water nexus: Breakfast cereals and snacks. Sustain. Prod. Consum. 2, 17-28. https://doi.org/10.1016/j.spc.2015.08.001

Lemming, G., Friis-Hansen, P., Bjerg, P.L., 2010. Risk-based economic decision analysis of remediation options at a PCE-contaminated site. J. Environ. Manage. 91, 1169-1182. https://doi.org/10.1016/j.jenvman.2010.01.011 
Lévová, T., Hauschild, M.Z., 2011. Assessing the impacts of industrial water use in life cycle assessment. CIRP Ann. - Manuf. Technol. 60, 29-32. https://doi.org/10.1016/j.cirp.2011.03.005

Life Cycle Initiative, 2016. Global Guidance for Life Cycle Impact Assessment Indicators Volume 1.

Meron, N., Blass, V., Garb, Y., Kahane, Y., Thoma, G., 2016. Why going beyond standard LCI databases is important: lessons from a meta-analysis of potable water supply system LCAs. Int. J. Life Cycle Assess. 21, 1134-1147. https://doi.org/10.1007/s11367-016-1096-7

Murray, B.R., Zeppel, M.J.B., Hose, G.C., Eamus, D., 2003. Groundwater-dependent ecosystems in Australia: It's more than just water for rivers. Ecol. Manag. Restor. 4, 110-113. https://doi.org/10.1046/j.1442-8903.2003.00144.x

Mutel, C.L., Pfister, S., Hellweg, S., 2012. GIS-based regionalized life cycle assessment: how big is small enough? Methodology and case study of electricity generation. Environ. Sci. Technol. 46, 1096-103. https://doi.org/10.1021/es203117z

Northey, S.A., Madrid López, C., Haque, N., Mudd, G.M., Yellishetty, M., 2018. Production weighted water use impact characterisation factors for the global mining industry. J. Clean. Prod. 184, 788-797. https://doi.org/10.1016/j.jclepro.2018.02.307

Pastor, A. V., Ludwig, F., Biemans, H., Hoff, H., Kabat, P., 2014. Accounting for environmental flow requirements in global water assessments. Hydrol. Earth Syst. Sci. 18, 5041-5059. https://doi.org/10.5194/hess-18-5041-2014

Pfister, S., Bare, J., Benini, L., Berger, M., Bulle, C., Lathuilliere, M., Manzardo, A., Margni, M., Motoshita, M., Núñez, M., Pastor, A., Ridoutt, B., Worbe, S., Boulay, A.-M., 2015. Outcome of WULCA harmonization activities: recommended characterization factors for water footprinting. EXPO 2015 Conf. 1-19.

Pfister, S., Koehler, a, Hellweg, S., 2009. Assessing the Environental Impact of Freshwater 
Consumption in Life Cycle Assessment. Environ. Sci. Technol. 43, 4098-4104.

Quinteiro, P., Ridoutt, B.G., Arroja, L., Dias, A.C., 2017. Identification of methodological challenges remaining in the assessment of a water scarcity footprint: a review. Int. J. Life Cycle Assess. 117. https://doi.org/10.1007/s11367-017-1304-0

Rygaard, M., Arvin, E., Binning, P.J., 2009. The valuation of water quality: Effects of mixing different drinking water qualities. Water Res. 43, 1207-1218.

https://doi.org/10.1016/j.watres.2008.12.014

Schmied, H.M., Eisner, S., Franz, D., Wattenbach, M., Portmann, F.T., Flörke, M., Döll, P., 2014. Sensitivity of simulated global-scale freshwater fluxes and storages to input data, hydrological model structure, human water use and calibration. Hydrol. Earth Syst. Sci. 18, 3511-3538. https://doi.org/10.5194/hess-18-3511-2014

Smakhtin, V., Revenga, C., Döll, P., 2004. A Pilot Global Assessment of Environmental Water Requirements and Scarcity. Assessment 29, 307-317. https://doi.org/10.1080/02508060408691785

The Danish Statistical Yearbook, 2015. Population and elections. Popul. (English Ed.

Troldborg, L., Sørensen, B.L., Kristensen, M., Mielby, S., 2014. Afgrænsning af grundvandsforekomster - Tredje revision af grundvandsforekomster i Danmark. Danmarks og Grønlands Geologiske Undersøgelse Rapport 2014/58.

Villanueva-Rey, P., Quinteiro, P., Vázquez-Rowe, I., Rafael, S., Arroja, L., Moreira, M.T., Feijoo, G., Dias, A.C., 2018. Assessing water footprint in a wine appellation: A case study for Ribeiro in Galicia, Spain. J. Clean. Prod. 172, 2097-2107. https://doi.org/10.1016/j.jclepro.2017.11.210

WULCA, 2014. The AWaRe Method [WWW Document]. AWaRe. URL http://www.wulcawaterlca.org/project.html (accessed 10.13.16). 
Zeng, Z., Liu, J., Savenije, H.H.G., 2013. A simple approach to assess water scarcity integrating water quantity and quality. Ecol. Indic. 34, 441-449. https://doi.org/10.1016/j.ecolind.2013.06.012 


\section{Supplementary Information}

SI. 1: Qualitative information of the modeled changes for the three groundwater systems

Qualitative information

ATGW Currently the 5 million $\mathrm{m}^{3}$ water are abstracted here. In the assessment with and

Advanced treatment without 5 million $\mathrm{m}^{3}$ water abstraction, the 'with' scenario will be more precise, of polluted because the model is based on this scenario.

groundwater

STGW -

This GWB already has relatively high water abstraction. In the assessment of with

Simple treatment of and without 5 million $\mathrm{m}^{3}$ water abstraction, the 'without' scenario will be more groundwater precise, because the model is based on this scenario.

IRW This area has a high infiltration rate, and there is little abstraction in GWBs

Infiltration of connected. In the assessment of with and without 5 million $\mathrm{m}^{3}$ water abstraction, reclaimed water the 'without' scenario will be more precise, because the model is based on this scenario. To model an infiltration, we add 5 million $\mathrm{m}^{3}$ of water, assuming that 4 million $\mathrm{m}^{3}$ will reach the GWB. 
SI. 2: A conceptual figure of AGWaRe

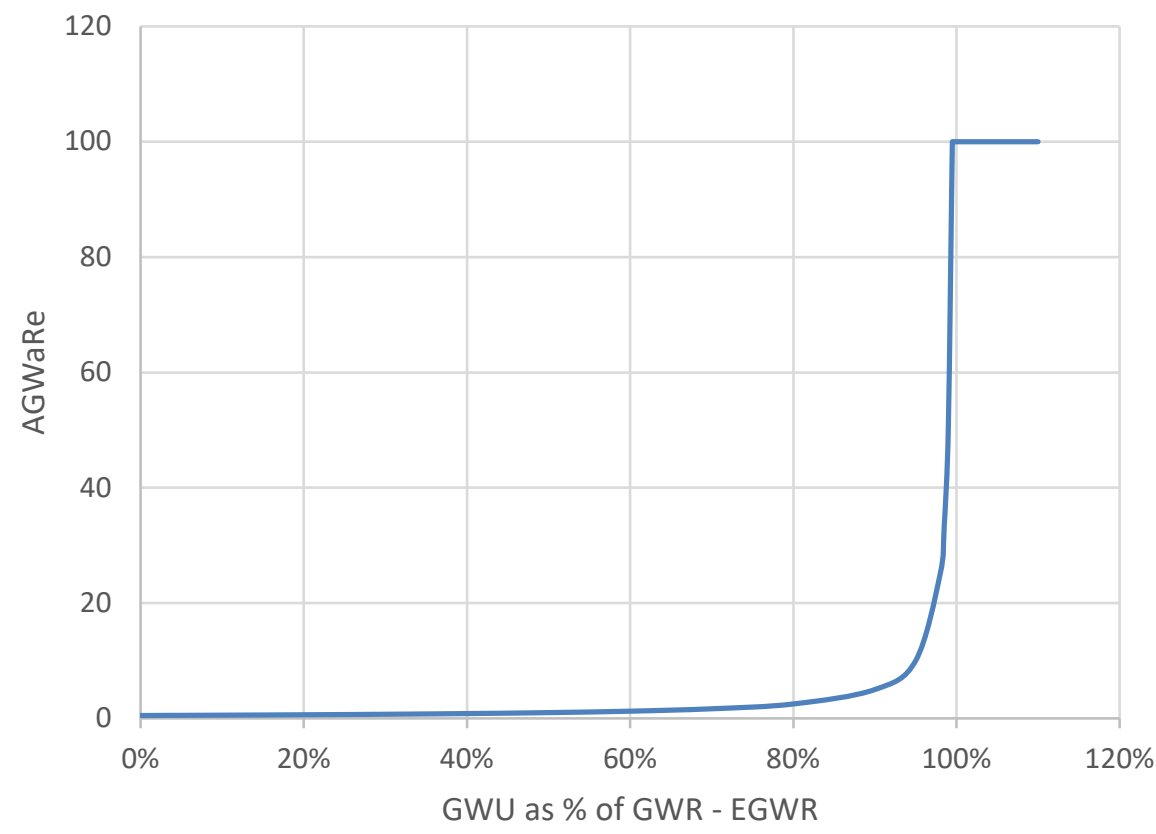

Figure 2: A conceptual figure of AGWaRe as a function of abstraction (GWU presented as a percentage of the remaining groundwater GWR-EGWR), with cut-off values below 0.1 and above 100. 
SI. 3: Inventory for producing 5 million $\mathrm{m}^{3}$ of drinking water

\begin{tabular}{|c|c|c|c|c|c|}
\hline & Source & ATGW & STGW & IRW & \\
\hline Raw water & & 5220844 & 5220844 & 5220844 & M3 \\
\hline Construction of well field & KE & & & & \\
\hline \multicolumn{6}{|l|}{ Capacity per well: $1000000 \mathrm{~m} 3 /$ years } \\
\hline No of wells & & 8 & 25 & 25 & \\
\hline Materials & KE & & & & \\
\hline Acid (konc. $\mathrm{HCl}$ ) & KE & 70000 & 70000 & 70000 & $\mathrm{~kg}$ \\
\hline Water use, for testing, flushing etc. & KE & 100000000 & 100000000 & 100000000 & 1 \\
\hline Concrete & KE & 7000 & 7000 & 7000 & $\mathrm{~kg}$ \\
\hline Steel & $\mathrm{KE}$ & 35000 & 35000 & 35000 & $\mathrm{~kg}$ \\
\hline PVC & KE & 27500 & 27500 & 27500 & $\mathrm{~kg}$ \\
\hline $\mathrm{PE}$ & $\mathrm{KE}$ & 32000 & 32000 & 32000 & $\mathrm{~kg}$ \\
\hline Pumps & KE & 2750 & 2750 & 2750 & $\mathrm{~kg}$ \\
\hline Diesel for boring & & 397 & 397 & 397 & I \\
\hline Diesel for trenches & & 1920 & 1920 & 1920 & I \\
\hline \multicolumn{6}{|l|}{ Water abstraction } \\
\hline Distance from well field to waterworl & & 5000 & 40000 & 20000 & \\
\hline Electricity for abstracting & & 109248 & 109248 & 109248 & \\
\hline Diesel & KE & 2358 & 2358 & 2358 & 1 \\
\hline Petrol & KE & 512 & 512 & 512 & 1 \\
\hline \multicolumn{6}{|l|}{ Pipe transport } \\
\hline Electricity & $\mathrm{KE}$ & 163872 & 2165001 & 1082501 & $\mathrm{kWh}$ \\
\hline Trench meters (from well field to wat & rworks) & 5000 & 40000 & 20000 & M \\
\hline Diesel, for making the trenches & & 12000 & 12000 & 12000 & $\mathrm{~L}$ \\
\hline PE for pipes & & 200000 & 1600000 & 800000 & $\mathrm{Kg}$ \\
\hline \multicolumn{6}{|l|}{ Construction of waterworks } \\
\hline \multicolumn{6}{|l|}{ Materials } \\
\hline Concrete & cowl & 1361500 & 1361500 & 1361500 & $\mathrm{~kg}$ \\
\hline Steel, & cowl & 84000 & 84000 & 84000 & $\mathrm{~kg}$ \\
\hline Masonry & COWI & 68000 & 68000 & 68000 & $\mathrm{~kg}$ \\
\hline
\end{tabular}




\begin{tabular}{|c|c|c|c|c|c|}
\hline Filter sand & COWI & 1121667 & 1121667 & 1121667 & $\mathrm{~kg}$ \\
\hline Sand to internal fitting & coWl & 2187500 & 2187500 & 2187500 & $\mathrm{~kg}$ \\
\hline Gravel & coWl & 258000 & 258000 & 258000 & $\mathrm{~kg}$ \\
\hline Soil to remove (externally) & coWl & 5445000 & 5445000 & 5445000 & $\mathrm{~kg}$ \\
\hline \multicolumn{6}{|l|}{ Soil to deposit } \\
\hline Aluminium & cowl & 6250 & 6250 & 6250 & $\mathrm{~kg}$ \\
\hline Electric articles & coWl & 15625 & 15625 & 15625 & $\mathrm{~kg}$ \\
\hline Pumps and fans & coWl & 4513 & 4513 & 4513 & $\mathrm{~kg}$ \\
\hline Chloride & coWl & 500 & 500 & 500 & $\mathrm{~kg}$ \\
\hline \multicolumn{6}{|l|}{ Water treatment } \\
\hline Methane & KE & 522084404 & 522084404 & 522084404 & $\mathrm{~g}$ \\
\hline Hydrogen sulphide & KE & 57429284 & 57429284 & 57429284 & $\mathrm{~g}$ \\
\hline Water for flushing & $\mathrm{KE}$ & 7470 & 7470 & 7470 & I \\
\hline Waste (ochre) & $\mathrm{KE}$ & 21892 & 21892 & 21892 & $\mathrm{~g}$ \\
\hline transport of waste & KE & & & 30 & $\mathrm{~km}$ \\
\hline
\end{tabular}

Additional inventory for the treatment of the contamination in case ATGW

\begin{tabular}{lll}
\hline ATGW Construction & & \\
Treatment of Contamination & \\
\hline Expected lifetime: 10 years & \\
Concrete & 159.31 & $\mathrm{~m} 3$ \\
Stainless steel & 11351 & $\mathrm{~kg}$ \\
Soil to remove & 666816 & $\mathrm{~kg}$ \\
Aluminium & 338 & \\
Electric articles & 845 & $\mathrm{Kg}$ \\
Pumps and fans (steel) & 2439 & $\mathrm{~kg}$ \\
PE, colons and Pipes & 29734 & $\mathrm{~kg}$ \\
PE, fillings for colons & 7180 & $\mathrm{~kg}$ \\
Operation & & \\
Electricity & & \\
C02 & 67126 & $\mathrm{Kwh}$ \\
\hline
\end{tabular}




\begin{tabular}{lll}
\hline PCE & 7.5 & $\mathrm{~kg} / \mathrm{year}$ \\
\hline
\end{tabular}

\section{Additional inventory in case IRW}

\begin{tabular}{lrl}
\hline IRW Infiltration & & \\
Construction of beds & & \\
\hline Concrete for pump station & 1600000 & $\mathrm{~kg}$ \\
and sedimentation basins & & \\
Steel & 2000 & $\mathrm{~kg}$ \\
PE & 80000 & $\mathrm{~kg}$ \\
Pumps & 1000 & $\mathrm{~kg}$ \\
Soil removal & 93000 & $\mathrm{~m} 3$ \\
diesel consumption & 22000 & $\mathrm{~m} 3$ \\
Diesel & 10442 & $\mathrm{l} / \mathrm{year}$ \\
Petrol & 15663 & $\mathrm{l} / \mathrm{year}$ \\
\hline
\end{tabular}

\begin{tabular}{lrl}
\hline Additional Pipe transport from wastewater treatment \\
\begin{tabular}{lrl} 
plant to infiltration beds & 1082501 & $\mathrm{kWh}$ \\
\hline Electricity & 20000 & $\mathrm{M}$ \\
Trench meters (from well field to & & \\
waterworks) & 12000 & $\mathrm{~L}$ \\
Diesel, for making the trenches & 800000 & $\mathrm{Kg}$ \\
PE for pipes & & \\
\hline
\end{tabular}
\end{tabular}




\section{SI. 4: Background Processes imported to Easetech}

\begin{tabular}{|c|c|c|c|c|c|}
\hline Process Name & Argument for choosing this process & Unit & Area & Year & $\begin{array}{l}\text { Link to } \\
\text { UPR for }\end{array}$ \\
\hline $\begin{array}{l}\text { Concrete production, for } \\
\text { building construction. with } \\
\text { cement CEM II/B. GLO }\end{array}$ & Concrete for buildings & $1 \mathrm{~m} 3$ & ROW & 2013 & concrete \\
\hline $\begin{array}{l}\text { Aluminium alloy production. } \\
\text { AlMg3 }\end{array}$ & $\begin{array}{l}\text { Production of alloy from primary } \\
\text { metals. no extra infrastructure. }\end{array}$ & $1 \mathrm{~kg}$ & Europe & $\begin{array}{l}1998- \\
2015\end{array}$ & $\begin{array}{l}\text { aluminiu } \\
\mathrm{m}\end{array}$ \\
\hline Chlorine production. liquid & $\begin{array}{l}\text { The only one called chlorine } \\
\text { production liquid }\end{array}$ & $1 \mathrm{~kg}$ & Global & $\begin{array}{l}2000- \\
2015\end{array}$ & chlorine \\
\hline $\begin{array}{l}\text { Tap water production. } \\
\text { underground water without }\end{array}$ & $\begin{array}{l}\text { Similar to our water treatment. It } \\
\text { represents average operation of tap }\end{array}$ & $1 \mathrm{~kg}$ & $\begin{array}{l}\text { Europe } \\
(-\mathrm{CH})\end{array}$ & $\begin{array}{l}2012- \\
2015\end{array}$ & $\begin{array}{l}\text { tap } \\
\text { water }\end{array}$ \\
\hline treatment & $\begin{array}{l}\text { water from underground water } \\
\text { without further treatments. }\end{array}$ & & & & \\
\hline $\begin{array}{l}\text { Market for } \\
\text { polyvinylchloride. bulk } \\
\text { polymerised }\end{array}$ & Lack of better knowledge & $1 \mathrm{~kg}$ & Global & $\begin{array}{l}2011- \\
2015\end{array}$ & PVC \\
\hline $\begin{array}{l}\text { Gravel/sand quarry } \\
\text { construction }\end{array}$ & $\begin{array}{l}\text { Written that it can be for } \\
\text { construction }\end{array}$ & 1 unit & ROW & $\begin{array}{l}1997- \\
2015\end{array}$ & gravel \\
\hline $\begin{array}{l}\text { Steel production, chromium } \\
\text { steel } 18 / 8 \text {. hot rolled }\end{array}$ & $\begin{array}{l}\text { Stainless steel. But many different to } \\
\text { choose from }\end{array}$ & $1 \mathrm{~kg}$ & Europe & $\begin{array}{l}2000- \\
2015\end{array}$ & steel \\
\hline $\begin{array}{l}\text { Electronics production. for } \\
\text { control units }\end{array}$ & $\begin{array}{l}\text { Electronics. with different } \\
\text { compartments }\end{array}$ & $1 \mathrm{~kg}$ & Europe & $\begin{array}{l}1990- \\
2015\end{array}$ & $\begin{array}{l}\text { electroni } \\
\text { cs }\end{array}$ \\
\hline $\begin{array}{l}\text { Polyethylene pipe } \\
\text { production, corrugated. DN }\end{array}$ & $\begin{array}{l}\text { Pipe for ventilation. but I assume } \\
\text { that it doesn't matter since I put it in }\end{array}$ & $1 \mathrm{~m}$ & Europe & $\begin{array}{l}2003- \\
2015\end{array}$ & $\mathrm{PE}$ \\
\hline 75 & kilo & & & & \\
\hline
\end{tabular}




\begin{tabular}{llllll}
\hline Carbon dioxide production. & Used for cooling (only four diff. & $1 \mathrm{~kg}$ & Europe & $1997-$ & carbon \\
liquid & options. market and this (with two & & & 2015 & dioxide \\
& geographical specifications)) & & & & \\
Hydrochloric acid & Only one called hydrochloric acid & $1 \mathrm{~kg}$ & Europe & $1997-$ & $\mathrm{HCl}$ \\
$\begin{array}{l}\text { production. from the } \\
\text { production. (with three different }\end{array}$ & & & 2015 & \\
$\begin{array}{l}\text { reaction of hydrogen with } \\
\text { chlorine }\end{array}$ & geographical references) & & & & \\
Transport, passenger car, & Used for driving of personal. medium & $1 \mathrm{~km}$ & Europe & $2012-$ & petrol \\
medium size, petrol. EURO 5 & car with good engine & & & 2015 & car \\
Transport, passenger car, & Used for driving of personal. medium & $1 \mathrm{~km}$ & Europe & $2012-$ & passeng \\
medium size, diesel. EURO 5 & cars with good engine & & 2015 & er car \\
\hline
\end{tabular}


SI. 5: Annual groundwater flows for the groundwater bodies for the three groundwater systems

Table 4: Annual groundwater flows for all the groundwater bodies for the three groundwater systems, for the current situation. The data are from the DK model (Henriksen et al., 2014) (from 2005-2010).

The groundwater bodies used in this analysis is 1,1 and 2 respectively.

\begin{tabular}{lllllll}
\hline & Connected & Area & GWU & GWR & EGWR: 30\% of & EGWR: 70\% of \\
& GWBs & $\left(\mathrm{km}^{2}\right)$ & $\left(\right.$ million $\left.\mathrm{m}^{3}\right)$ & $\left(\right.$ million $\left.\mathrm{m}^{3}\right)$ & GWR (million $\left.\mathrm{m}^{3}\right)$ & GWR (million $\left.\mathrm{m}^{3}\right)$ \\
\hline ATGW & 1 & 1160 & 63 & 80 & 24 & 56 \\
& 2 & 102 & 0.2 & 21 & 6.3 & 15 \\
STGW & 1 & 1315 & 29 & 45 & 14 & 31 \\
IRW & 1 & 156 & 0.8 & 1.5 & 0.5 & 1.0 \\
& 2 & 612 & 3.4 & 103 & 31 & 72 \\
& 225 & 0.7 & 13 & 3.9 & 9.0 \\
\hline
\end{tabular}




\section{SI. 6: LCA impacts for the three groundwater systems}

The LCA impacts related to abstracting and cleaning 5 million $\mathrm{m}^{3}$ of water is seen in figure 7 . The impacts range between 1 and $874 \mathrm{PE}$ in the different impact categories. The highest contributions to impact categories are within resource impact categories, ranging between 52 and 874 PE. For toxic impact categories, the impacts range between 21 and 151 PE. For environmental impact categories, the impacts range between 0 and $159 \mathrm{PE}$. These are relatively small environmental impacts from the drinking water production to approximately 100.000 people. Comparing between the groundwater systems it is seen that generally case IRW, has the highest environmental impacts, then case STGW, and with lowest impacts is case ATGW. Except for the impact category Freshwater Eutrophication and Abiotic Resource Depletion, the LCA shows that ATGW has higher impacts than the other cases, but the impacts are below $10 \%$ differences and therefore not significant.

The impacts from case STGW and IRW are similar; this is because the only modelled difference between the two cases is the infiltration bed, incl. materials, operation and construction.

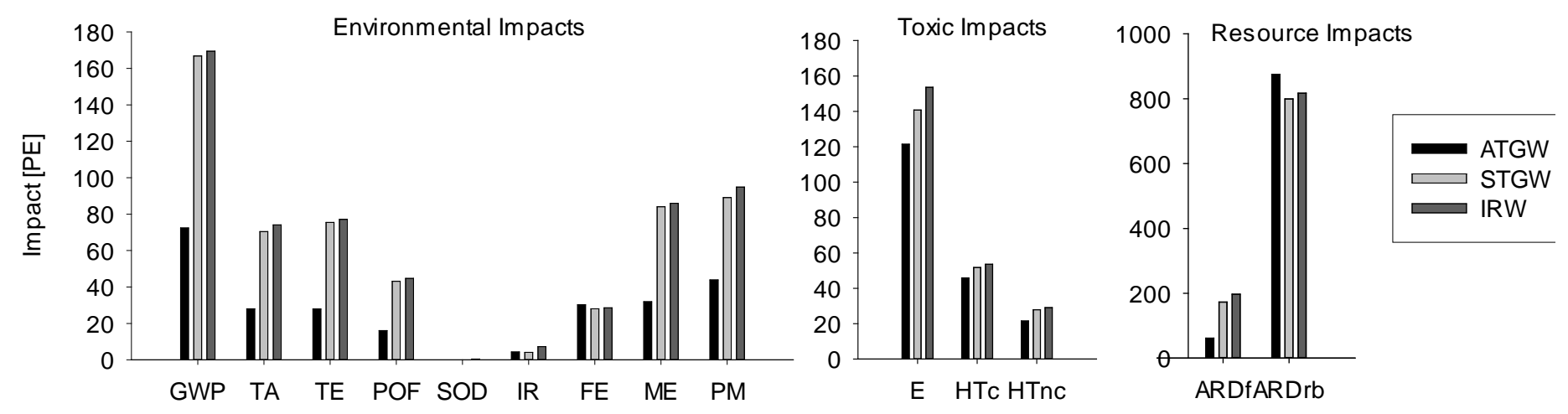

Figure 7: The results from the comparative LCA of three groundwater systems producing water for 100.000 people. Impact categories abbreviations: Global Warming Potential (GW), Terrestrial Acidification (TA), Terrestrial Eutrophication (TE), Photochemical Oxidant Formation (POF), Stratospheric Ozone Depletion (SOD), Human Toxicity (carcinogenic) (HTc), Human Toxicity (non-carcinogenic) (HTnc), Ionising Radiation (IR), Freshwater Eutrophication (FE), Marine Eutrophication (ME), Ecotoxicity (E), Abiotic Resource Depletion (fossil) (ARDf), Abiotic Resource Depletion (reserve base) (ARDrb) and Particulate Matter (PM). 


\section{SI. 7: Contribution analysis}

A contribution analysis show that Transportation, abstraction, things connected to water abstraction, wiring of PCE, waterworks and infiltration contributes to more than $10 \%$ in at least one of the impact categories.

Only $\mathrm{CO} 2$ emissions, Wastewater treatment (from the waterworks) and emissions do not contribute to more than $10 \%$ to any impact category. 


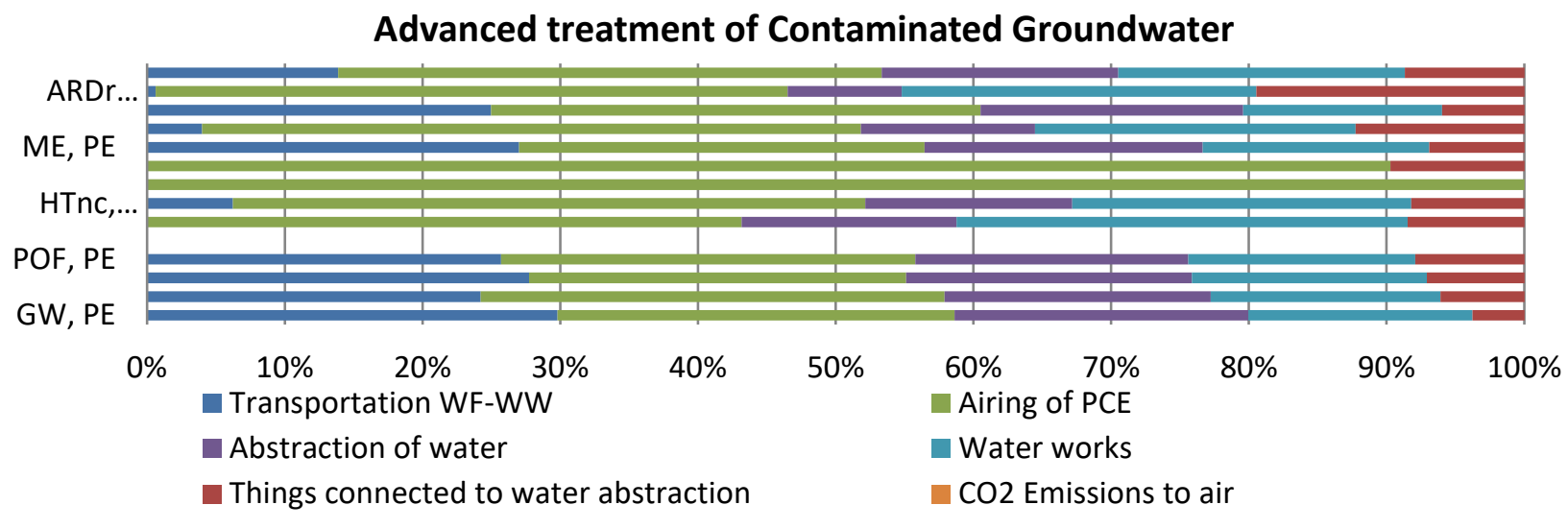

\section{Simple Treatment of Groundwater}

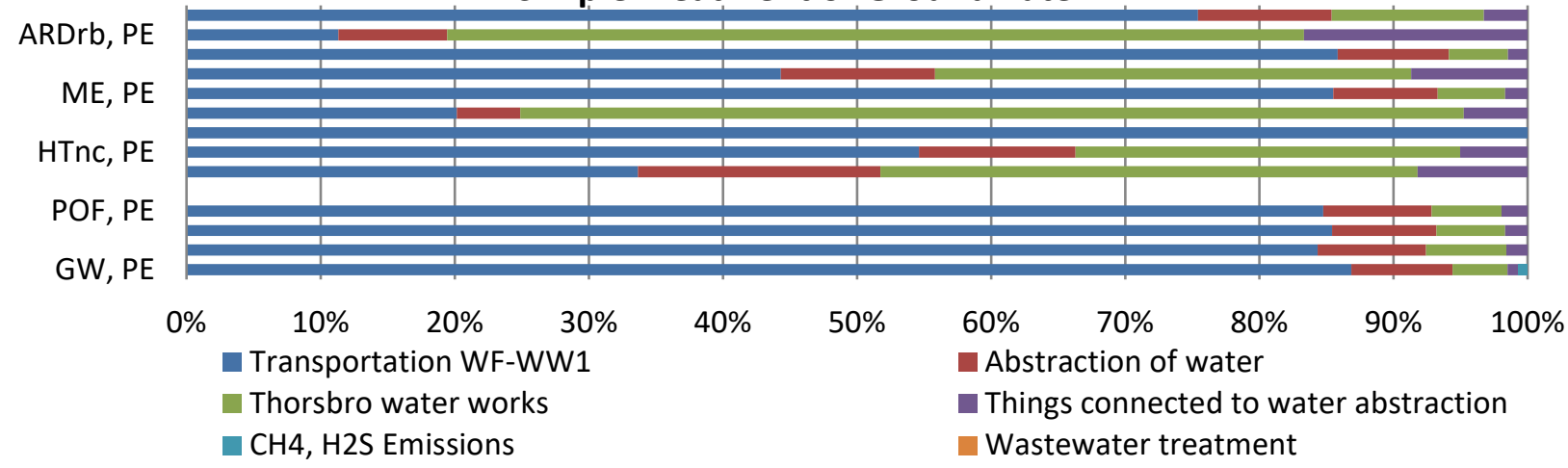

Infiltration of Reclaimed water

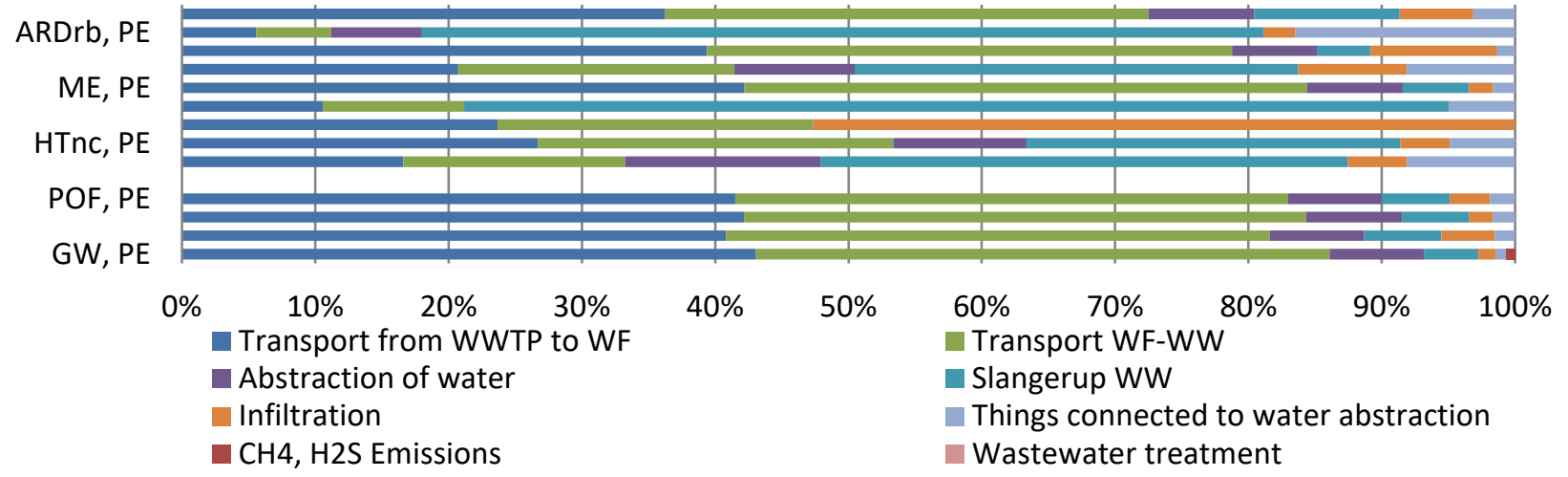




\section{SI. 8: Sensitivity ratios for the three most contributing inputs}

Sensitivity ratios for the three most contributing inputs for each case for three impact categories:

Abiotic Resource Depletion (reserve base), Global Warming Potential Human Toxicity - carcinogenic

Table 1: Sensitivity analysis results for the impact categories given for the three most influential parameters for each category. The sensitivity ratio (SR) is the ratio between the percentage change in model input and the percentage change in model output (parameter in LCA). The input parameter is changed by $10 \%$ one at a time.

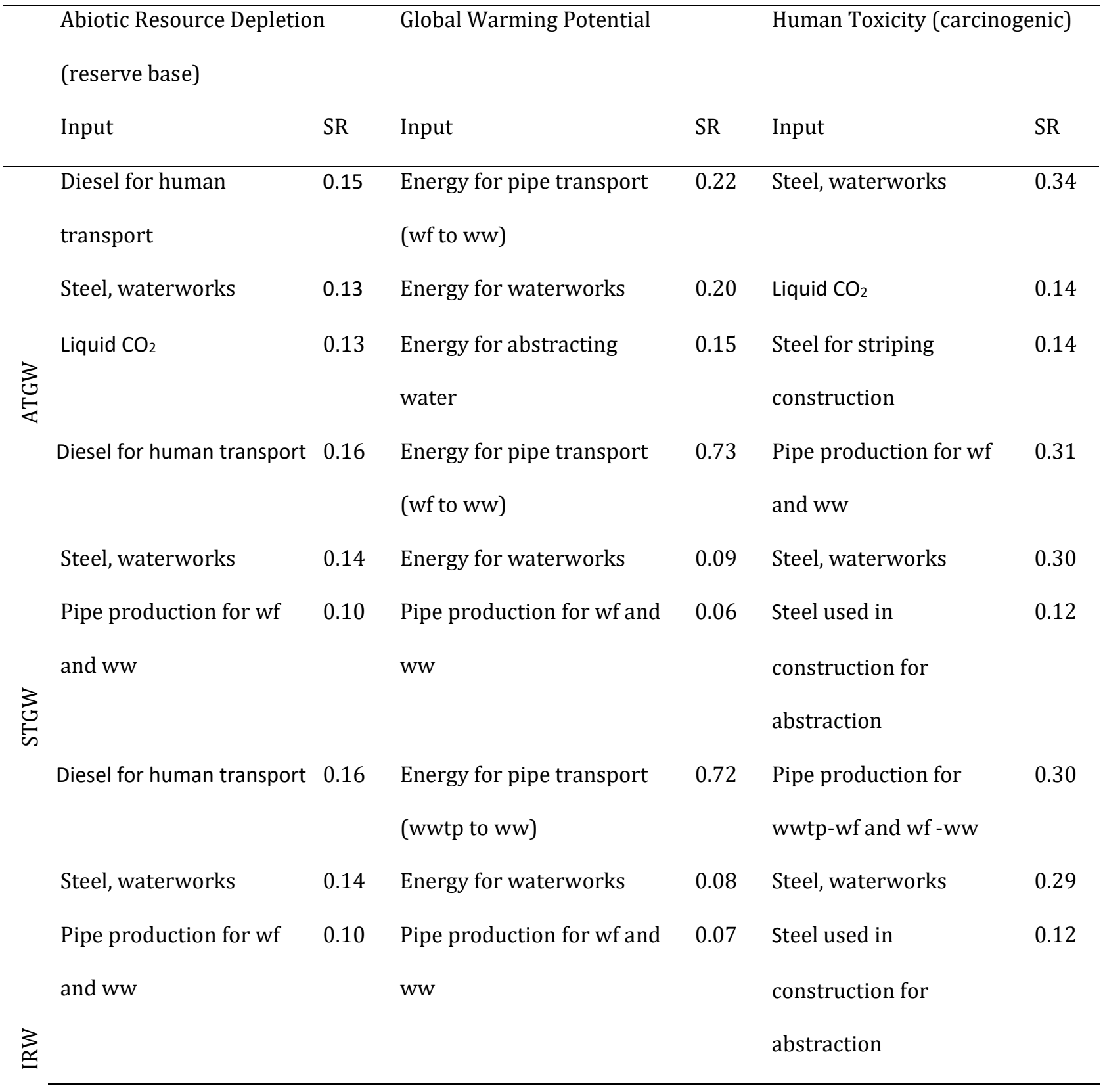




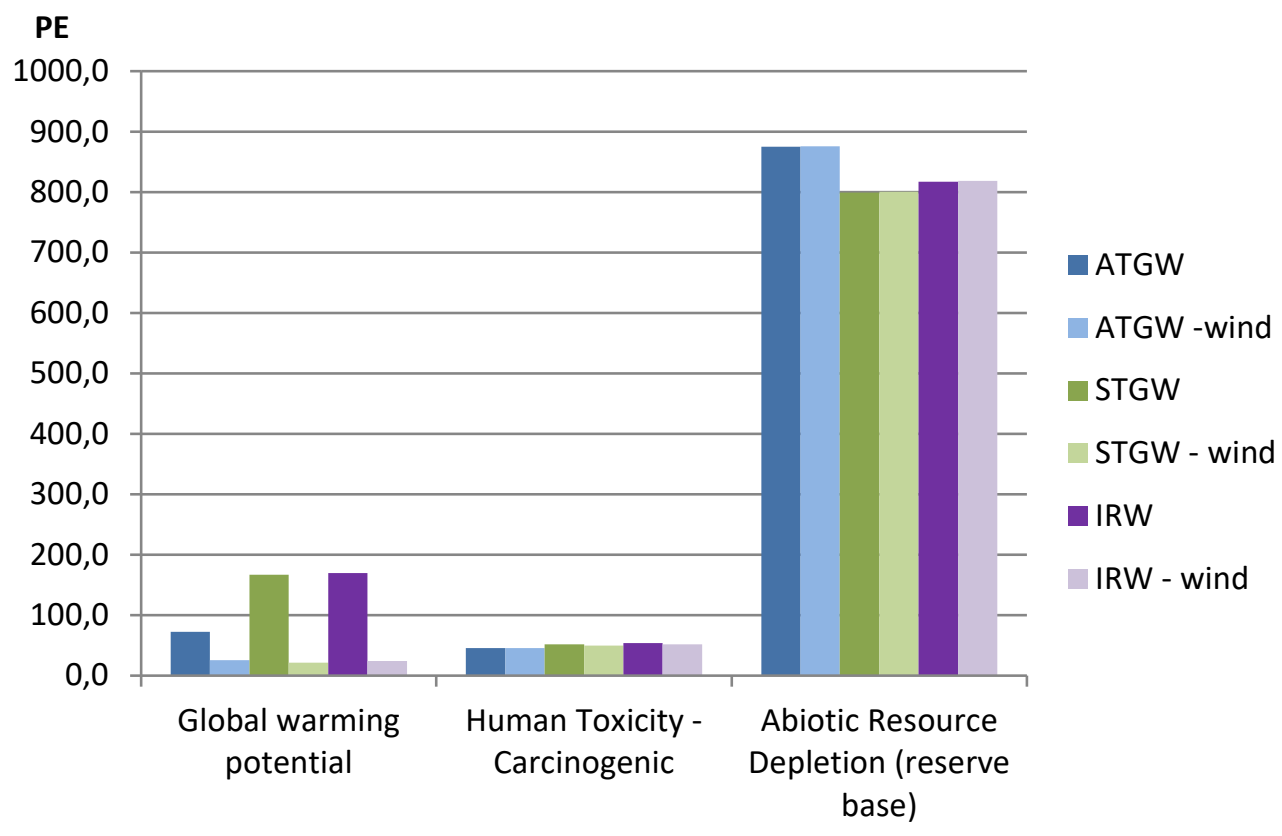

The impacts of three groundwater systems producing 5 million $\mathrm{m}^{3}$ of water, when the energy comes from 1) average electricity mix - Denmark and 2) from wind energy for the three impact categories Global Warming Potential, Human Toxicity (carcinogenic) and Abiotic Resources Depletion (reserve base). 